\title{
DESSACRALIZANDO AS PROPRIEDADES: UM ESTUDO SOBRE 0 AFORAMENTO URBANO E A MENTALIDADE PROPRIETÁRIA DO INÍCIO DO SÉCULO XX EM NATAL (RN)
}

Desecrated Properties: A Study On The Urban Aforamento And The Owner Mindset On The Beginning Of Twentieth Century In Natal (RN)

\author{
Gabriela Fernandes Siqueira \\ Mestre em História pelo Programa de Pós-Graduação em História da UFRN \\ gabifernande_s@hotmail.com
}

\section{Resumo}

Este artigo objetivou analisar a política de apropriação do solo urbano do terceiro bairro de Natal entre 1901 e 1919, bem como os usos que os sujeitos fizeram desse solo. No período estudado, os sujeitos apropriavam-se do solo urbano de Cidade Nova por meio do instituto do aforamento. Pretende-se investigar as leis federais e estaduais que definiram o aforamento, relacionando-as com as resoluções que regulavam as enfiteuses existentes em Natal e, sobretudo, em Cidade Nova no período estudado.Com esse estudo pode-se demonstrar como a capital do estado, que iniciou o século XX com discursos progressistas, continuou com uma política de terras tradicional, concluindo que a mentalidade proprietária moderna não foi plenamente estabelecida em Natal no período estudado.

\section{Palavras-chave}

Solo urbano, aforamento, Natal

\begin{abstract}
This article has the objective to analyze the political appropriation of urbanland in the third district of Natal between 1901 and 1919 as well as the uses towhich the subjects made this soil. In the period studied, subjects are appropriated urbanland of Cidade Nova by the Institute of aforamento. We intend to investigate the federal and state laws that defined aforamento relating hem to there solutions regulating existing enfiteuses in Natal, and especially in Cidade Nova in the period studied. With this study, we could demonstrate how the capital of the state that started the twentieth century with progressive discourses continued with a policy of traditional lands,
\end{abstract}


exemplifying how modern proprietary mindset was not fully established in Natal during the study period.

\section{Keywords}

Urbanland, aforamento, Natal

\section{Introdução}

O objetivo deste artigo é realizar um estudo sobre o instituto do aforamento urbano em Natal, Rio Grande do Norte, enfatizando a aplicação desse instituto no bairro Cidade Nova no início do século XX. O bairro Cidade Nova, oficializado em 1901 por meio da assinatura da Resolução n.55 (A REPUBLICA, 04 jan. 1902), tornou-se território oficial da cidade por meio de uma intervenção do poder municipal em parceria com o governo estadual.

O novo território foi representado nas fontes oficiais, nas leis e decretos dos poderes estadual e municipal, nas mensagens de governadores e relatórios de intendentes como local promissor. Região saudável, salubre, perto do mar, propiciadora de um ambiente idílico, em que os bons ares vindos do mar circulariam nas propriedades construídas, respeitando os ideais de salubridade e higienismo vigentes no período.

Cidade Nova era exaltada pelos representantes do poder local como um bairro capaz de representar a nova condição política do Rio Grande do Norte e de sua capital no contexto republicano, remodelando a cidade que, segundo esse mesmo discurso, iniciou o século XX ainda envolta por características provincianas, com ruas estreitas, tortuosas, com bairros que alagavam. Com uma configuração espacial confusa, que misturava funções diversas.

Com a implantação do governo republicano, tem-se novo arranjo político na esfera estadual. Foi nesse período que um novo grupo familiar, os Albuquerque Maranhão (juntamente com sua rede de parentela e amizade) ${ }^{1}$, assumiu o poder no estado do Rio Grande do Norte, e seus interesses deixaram de ser conquistados por

\footnotetext{
${ }^{1}$ Para uma análise mais profunda sobre as diferentes correntes que circularam entre os republicanos norte-rio-grandenses e sobre a forma como essas ideias foram aplicadas, ver o livro fruto da tese de Bueno ou consultar diretamente o texto da tese: BUENO, Almir de Carvalho. Visões de República: ideias e práticas políticas no Rio Grande do Norte (1880-1895). Natal: Editora da UFRN, 2002; BUENO, Almir de Carvalho. Visões de República: ideias e práticas políticas no Rio Grande do Norte (1880-1895). Tese (Doutorado em História). Programa de Pós-Graduação em História, Universidade Federal de Pernambuco (UFPE), Recife, 1999.

URBANA, V.6, no 9, ago-dez, 2014 - Dossiê: Dimensões Simbólicas das Intervenções Urbanas CIEC/UNICAMP
} 
meio de uma ordem baseada na fluidez do espaço (PEIXOTO, 2012, p.19) ${ }^{2}$. Nessa nova realidade, em que fazia sentido a preocupação com unidades federativas e não mais apenas com o todo, em que os estados adquiriam maior autonomia, as ambições dos grupos familiares seriam atendidas somente por meio do controle do aparelho local.

Controlando o governo do estado, os grupos familiares poderiam dispor dos recursos de uma unidade estadual e conseguir mais benefícios por meio de seus representantes junto ao governo central. No início do século XX, no Rio Grande do Norte, a família Albuquerque Maranhão controlava o poder na esfera estadual e implementou, juntamente com o apoio da Intendência Municipal de Natal, uma série de mudanças que visavam criar uma nova forma para a cidade. Esse grupo esforçouse em construir uma espacialidade e identidade norte-rio-grandense, representando esse período como promissor, como diferente do anterior, do imperial, em que, segundo esse discurso, a cidade era envolta por características provincianas e atrasadas.

Tratava-se de um momento em que esses grupos dirigentes queriam afirmarse na cidade, e, para tanto, inscreviam-se nas toponímias da urbe, nos novos espaços criados, como o terceiro bairro - Cidade Nova -, e, especialmente, na historiografia estadual e local, que começou a ser escrita e disseminada nesse período ${ }^{3}$.

Os membros da Intendência Municipal eram indicados pela chefia estadual do Partido Republicano Federal, composto principalmente pelos membros do grupo familiar Albuquerque Maranhão, e então eram levados à eleição. Em Natal, assim como na maior parte das cidades brasileiras nesse período, a oposição não tinha muito espaço. Os nomes indicados pelo partido estadual na maioria das vezes saíam vencedores, já que as eleições eram marcadas por processos fraudulentos e existiam relações de amizades e parentesco que ligavam os membros do governo estadual aos intendentes. A autonomia municipal garantida pelas constituições estaduais era na realidade um instrumento dos governos federais e estaduais para assegurar a vitória nas eleições. Na prática, o poder municipal era pouco autônomo, tendo, muitas vezes,

\footnotetext{
2 Para entender como ocorreu a ascensão desse grupo político no cenário local e quais as suas vinculações políticas, ver: SIQUEIRA, Gabriela Fernandes de. Por uma "Cidade Nova": apropriação e uso do solo urbano no terceiro bairro de Natal (1901-1929). Dissertação (Mestrado em História). Programa de Pós-Graduação em História, Universidade Federal do Rio Grande do Norte (UFRN), Natal, 2014.

3 Para uma análise sobre o sentido de identidade e espacialidade norte-rio-grandense presente na historiografia do início do século XX e, sobretudo, na obra de Tavares de Lyra, ver: BRITO, Anderson Dantas da Silva. Em nome(s) dos interesses: imaginários toponímicos do Rio Grande do Norte na Primeira República. Dissertação (Mestrado em História). Universidade Federal do Rio Grande o Norte. Natal, 2012.

URBANA, V.6, no 9, ago-dez, 2014 - Dossiê: Dimensões Simbólicas das Intervenções Urbanas CIEC/UNICAMP
} 
que atender aos mandos e desmandos do grupo familiar que ocupava o governo estadual.

Atuar como intendente significava, portanto, participar de um sistema de valor e de uma ordem política envolta por redes de dependência e favor, em que muitos indivíduos ligados a essa ordem eram tratados de forma diferenciada perante a legislação. Os membros da Intendência e seus aliados descumpriam as leis que criavam, muitos atuavam como verdadeiros negociantes de terras do município, desrespeitando as regras de aforamento, medição e construção determinadas pelas resoluções publicadas no início do século $X X$. O descumprimento da legislação também era facilitado pela dificuldade de fazer cumprir as regras estabelecidas pelas resoluções. O número de fiscais da Intendência era restrito e a dificuldade de fiscalizar os bairros e povoados da cidade era significativa.

Os dois bairros urbanos da cidade, Ribeira e Cidade Alta, eram representados pelo discurso local como atrasados, sem padrão, sem regras, uma vez que não foram planejados previamente. Esses dois bairros eram mencionados pelo jornal oficial do Partido Republicano Federal do Rio Grande do Norte, o A Republica, como compondo a "cidade velha", sem planejamento, com péssimas condições sanitárias, propiciadora de doenças. Espaço em que os mais ilustres e abastados tinham que conviver com os populares e, consequentemente, com hábitos que passaram a ser criticados pelo poder local. Tratavam-se de bairros cuja ocupação acompanhou o crescimento populacional, não tendo uma planta elaborada previamente, conforme ocorreria com o planejado terceiro bairro oficial.

A planificação de Cidade Nova demonstrava o interesse do poder local voltado para criar uma área preferencialmente, embora não exclusivamente, residencial, com novos padrões para construções de moradias. As casas não deveriam ser geminadas, sem espaçamento entre si, como as residências existentes em Cidade Alta e Ribeira. Regras deveriam ser seguidas. O novo bairro também seria ocupado por determinadas instituições como cafés, clubes, associações, hotéis, praças. Equipamentos com funções pedagógicas capazes de auxiliar na formação daquele grupo, difundindo comportamentos e criando valores, contribuindo ainda mais para o estreitamento de laços entre os mais abastados e influentes.

Antes de ser concretizado enquanto bairro oficial, esse território foi pensado, imaginado, idealizado por determinado grupo, carregando interesses específicos. Antes de ser ocupada de forma oficial, essa área foi esquadrinhada por meio de um plano urbanístico que anunciou a primeira expansão urbana da capital.

URBANA, V.6, no 9, ago-dez, 2014 - Dossiê: Dimensões Simbólicas das Intervenções Urbanas CIEC/UNICAMP 


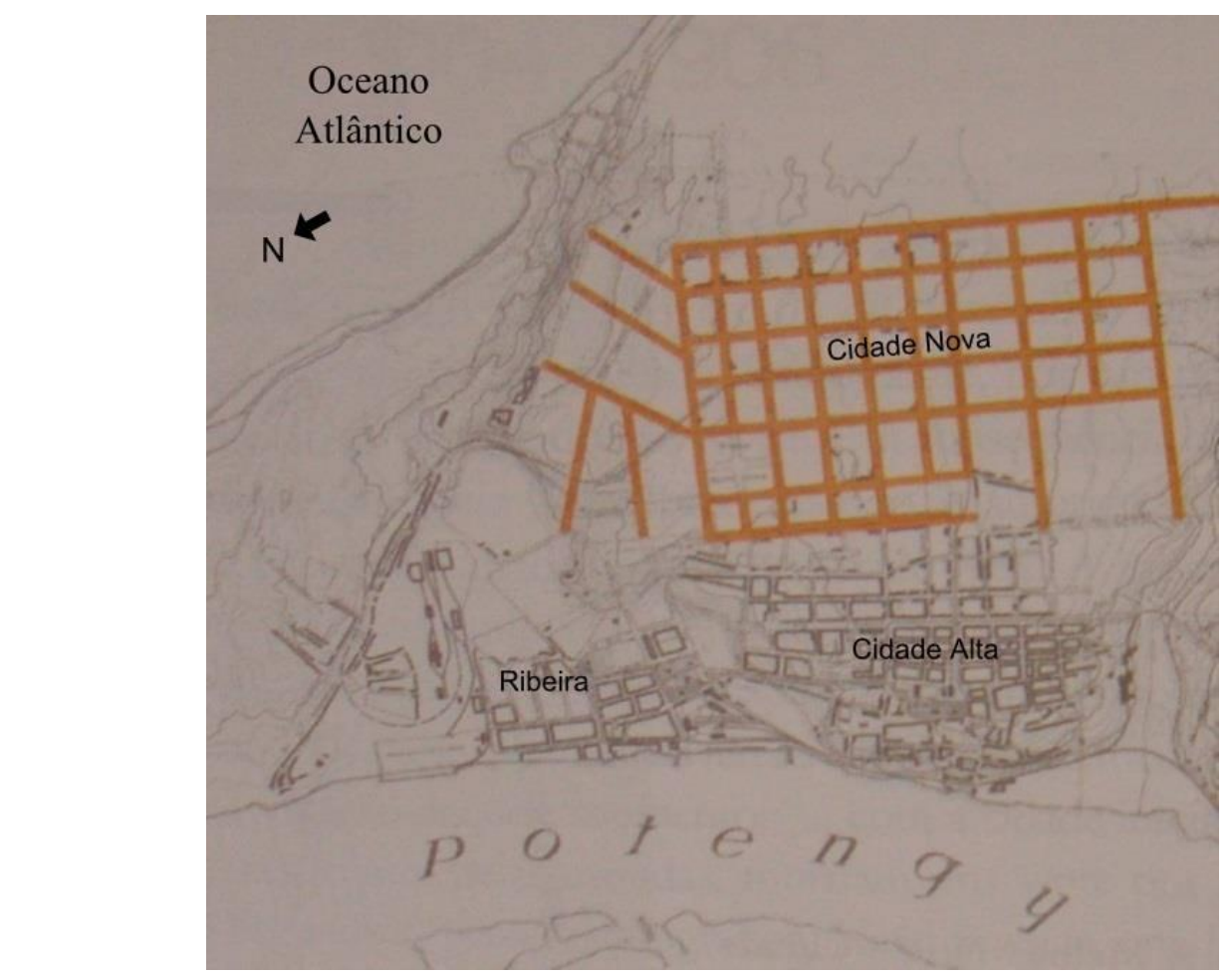

Figura 1 - Representação dos bairros Ribeira, Cidade Alta e Cidade Nova (em destaque)

Fonte: Recorte e adaptação do mapa encontrado em: (FERREIRA et al, 2008, P.63)

Como é possível observar pelo mapa acima destacado, após a intervenção do poder local em 1901, criando Cidade Nova, Natal não mais seria restrita à sua área central. Ganhava um novo bairro com dimensões que ultrapassavam os dois bairros já existentes. Também é possível observar no mapa como nos dois outros bairros, Ribeira e Cidade Alta, não existia um alinhamento padronizado, diferentemente do novo bairro, formado por quarteirões alinhados, com largas e retilíneas avenidas.

De fato, é possível observar que o bairro Cidade Nova não foi pensado como uma região qualquer, de livre ocupação. Apesar de algumas resoluções municipais determinarem áreas para concessão de terras aos menos abastados, o planejamento do bairro era destinado a um grupo específico. O novo território era voltado para abrigar àqueles indivíduos influentes, que frequentavam os clubes e espaços de sociabilização mais importantes da capital, que ocupavam cargos políticos ou que estabeleciam relações de reciprocidade com membros do governo estadual e local. Sujeitos que possuíam condições financeiras para construir verdadeiros palacetes no território criado.

Em 1901, o poder municipal planejou esse bairro para que esses sujeitos pudessem conviver com uma natureza aprazível, com uma área que não enfrentava os problemas característicos da cidade representada como "velha". Seria uma região que possuiria equipamentos técnicos, como linhas de bondes, água encanada, energia URBANA, V.6, no 9, ago-dez, 2014 - Dossiê: Dimensões Simbólicas das Intervenções Urbanas CIEC/UNICAMP 
elétrica, e ainda manteria seu caráter idílico, a aproximação com elementos da natureza. Seria uma área singular, modernizada e ao mesmo tempo longe dos problemas característicos de uma região já bastante ocupada.

No momento em que esse bairro foi idealizado a cidade enfrentava uma série de mudanças em seu espaço urbano. Não somente um novo bairro foi oficializado, mas a "cidade velha" também sofreu várias intervenções. Um teatro foi construído na Ribeira, obras de aterramento e alinhamento foram projetadas para esse bairro. Praças, jardins, reforma do porto, entre outros melhoramentos urbanos também foram concretizados em Cidade Alta e Ribeira.

Assim, o bairro Cidade Nova foi idealizado nesse momento em que o poder local tencionava construir uma nova imagem para a capital. O novo bairro representava em sua própria toponímia esse desejo, de aproximar Natal a reformas de modernização que ocorriam em outras cidades e até mesmo nos considerados civilizados países da Europa. Suas ruas, praças e avenidas possuíam nomes de presidentes do período republicano, de rios importantes do estado e de líderes republicanos locais. A praça principal de Cidade Nova, por exemplo, foi denominada praça Pedro Velho. Homenageava-se e exaltava-se na pedra o nome daquele indivíduo que liderou a organização familiar Albuquerque Maranhão e que foi responsável por consolidar a influência dessa família no Rio Grande do Norte principalmente a partir de 1895.

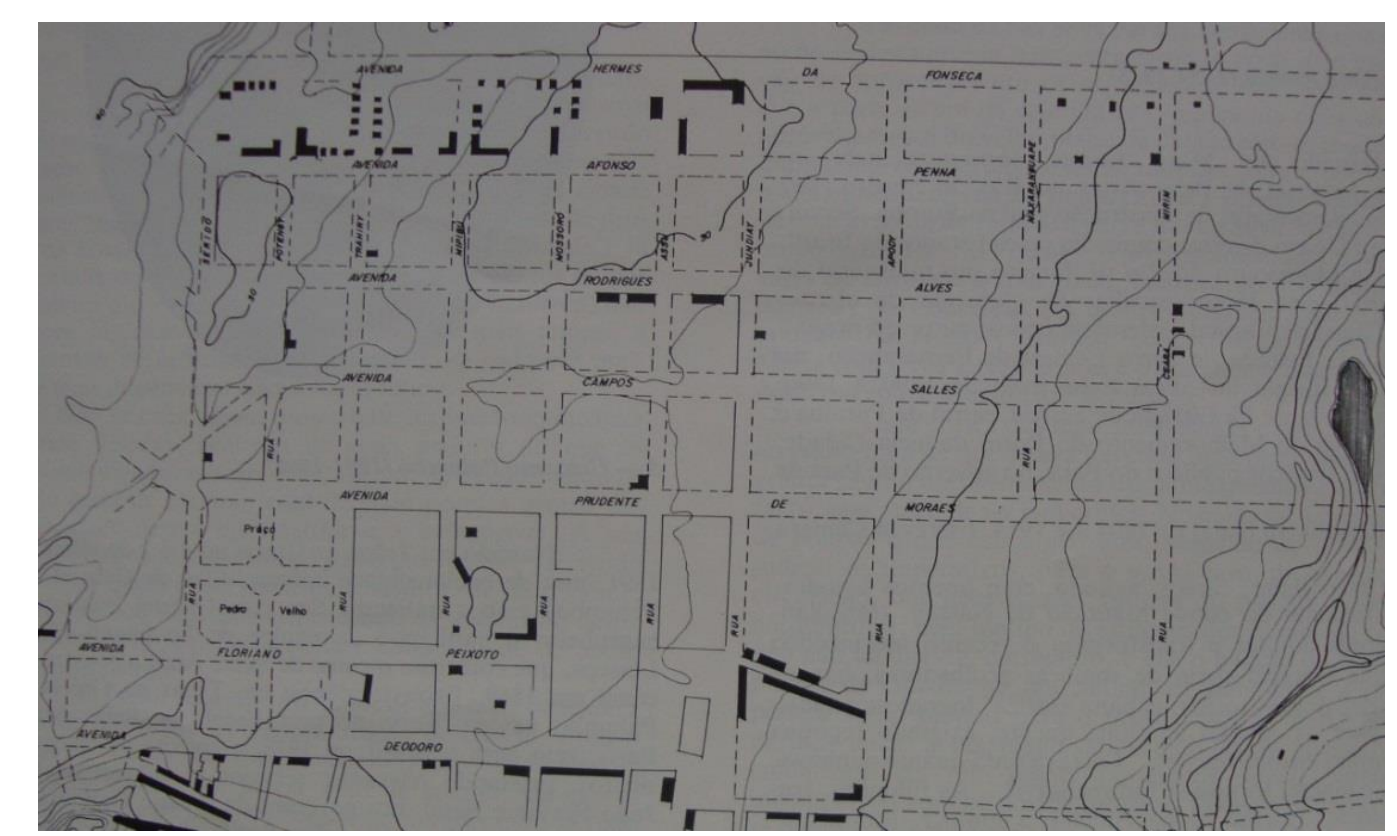

Figura 2 - Representação do bairro Cidade Nova destacando o nome de suas avenidas, ruas e praças Fonte: (MIRANDA, 1981)

URBANA, V.6, no 9, ago-dez, 2014 - Dossiê: Dimensões Simbólicas das Intervenções Urbanas CIEC/UNICAMP 
As reformas não ficaram restritas apenas ao espaço material da urbe. Era também necessário modificar hábitos e comportamentos. A Intendência Municipal de Natal durante 0 início do século $X X$ formulou diversas resoluções municipais determinando mudanças de comportamento na área urbana da cidade. Existia a intenção de definir com segurança o que era a área urbana e diferenciá-la da área rural. No espaço urbano não seria mais tolerado a pastagem de vacas, burros e outros animais. Nesse espaço também não mais seria permitido criar porcos nos quintais, construir casas sem espaçamento, lançar dejetos em praças e jardins, destruir a arborização, urinar nas proximidades de mercados, entre diversas outras atitudes que pareciam ser frequentes na cidade.

Assim, neste artigo pretende-se analisar a política de apropriação do solo urbano do terceiro bairro de Natal entre 1901 e 1919, bem como os usos que os sujeitos fizeram desse solo. No período estudado, os sujeitos apropriavam-se do solo urbano de Cidade Nova por meio do instituto do aforamento, também denominado enfiteuse. Pretende-se ainda investigar as leis federais e estaduais que definiram o aforamento, relacionando-as com as resoluções que regulavam as enfiteuses existentes em Natal e, sobretudo, em Cidade Nova no período estudado.

Dessa maneira, a capital do estado que iniciou o século XX com discursos progressistas continuou com uma política de terras tradicional, que privilegiava as relações pessoais em diversos momentos, ao mesmo tempo em que, em outras ocasiões, a terra era utilizada com função especulativa, lucrativa economicamente. Como será exemplificado neste trabalho, a mentalidade proprietária moderna não tinha sido plenamente estabelecida em Natal no início do século XX.

Essa pesquisa sobre o aforamento urbano em Cidade Nova fornecerá uma contribuição aos estudos relacionados à propriedade da terra na cidade. Estudos sobre as questões de terras no Brasil são predominantemente referentes ao cenário rural (GLEZER, 2007, p.15). Em Natal, a situação não é diferente. Estudos propriamente voltados para questões de terras urbanas na cidade foram produzidos principalmente para explicar o período a partir de $1946^{4}$. Dessa maneira, o trabalho aqui proposto é um desafio e pode contribuir para iniciar a compreensão dos estudos sobre os aforamentos urbanos em Natal no início do século XX.

\footnotetext{
${ }^{4}$ Destaca-se a tese da professora Angela Ferreira: FERREIRA, Angela Lúcia. De La producción del espacio urbano a La creación de território sem La ciudad: um estudio sobre La constitución de lo urbano en Natal, Brasil. Tese (Doutorado em Geografia Humana). Universidade de Barcelona, Barcelona, 1996.

URBANA, V.6, no 9, ago-dez, 2014 - Dossiê: Dimensões Simbólicas das Intervenções Urbanas CIEC/UNICAMP
} 


\section{0 instituto do aforamento urbano e a mentalidade proprietária do início do século XX}

Antes de partir para a análise da legislação municipal que regulamentava a política de apropriação e uso do solo urbano de Cidade Nova, é necessário discorrer sobre o significado do instituto aforamento e sobre a mentalidade proprietária existente no Rio Grande do Norte e, consequentemente, em sua capital no início do século XX. É preciso desmistificar a ideia de que a partir do século XIX se poderia ter acesso à propriedade somente por meio da compra ${ }^{5}$. É necessário, pois, dessacralizar a propriedade, não a compreender como única, unitária, observá-la como uma construção fruto do seu tempo (GROSSI,2006).

O aforamento, enfiteuse ou aprazamento é um direito real, ou seja, um direito exercido diretamente sobre a coisa a ele aderente ou inerente, em oposição a um direito pessoal, exercido sobre o sujeito de uma obrigação. Segundo Edgar Amorim, o aforamento é estabelecido mediante contrato perpétuo, em que o titular da propriedade confere a outrem os poderes de seu uso, gozo e disposição (AMORIM, 1986, p.1).

O vocábulo enfiteuse tem origem grega, mas seus contornos substanciais são provenientes do Direito Romano. No Direito Romano a enfiteuse desenvolveu-se com base no instituto do arrendamento público, quando, ao invés de temporário, o contrato passou a admitir a perpetuidade ${ }^{6}$. Em Roma, a enfiteuse foi inicialmente aplicada às terras públicas, atendendo às exigências da administração e exploração das terras estatais. Mesmo nesse período e atendendo ao interesse dos governantes, Amorim ressaltou que existia o regulamento por meio da forma contratual.

No período medieval, a natureza da enfiteuse passou por uma profunda mudança. Foi nesse período que a propriedade foi dividida em domínios superpostos, fazendo com que seu caráter unitário desaparecesse. O domínio passou a ser direto, também denominado de domínio do senhorio, ou útil, quando fosse domínio do enfiteuta (AMORIM, 1986, p. 1-2). O foreiro tinha como obrigação principal pagar um taxa, foro ou canon anual para o senhorio, aquele que detinha o domínio direto da terra.

\footnotetext{
${ }^{5}$ Muitos autores brasileiros guiados por uma interpretação reducionista da Lei n. 601 , de 18 de setembro de 1850, também conhecida como Lei de Terras, compartilharam essa opinião limitadora, não compreendendo que propriedade é mentalidade, e que a propriedade moderna, plena, abstrata e simplificada, como ficou conhecida por volta da transição do século XIX para o séc. XX, levou tempo para ser incorporada e conviveu com diversas continuidades.

${ }^{6} \mathrm{~A}$ enfiteuse difere-se do arrendamento por ser um direito real perpétuo, enquanto o arrendamento é um direito pessoal, concedido a determinado sujeito, e possui tempo limitado.

URBANA, V.6, no 9, ago-dez, 2014 - Dossiê: Dimensões Simbólicas das Intervenções Urbanas CIEC/UNICAMP
} 
Sérgio Said Júnior, em sua tese intitulada $A$ posse no Direito brasileiro da segunda metade do século XIX ao Código Civil de 1916, ressaltou a importância de compreender alguns aspectos da concepção de propriedade da sociedade medieval, pois é nela que se desenvolveram noções interessantes envolvendo coisas e pessoas, bem diversas das existentes no período considerado moderno e que influenciaram o direito brasileiro até mesmo após a publicação do Código Civil de 1916. Para Said Júnior, o próprio direito no Brasil do século XIX ainda possuía várias características provenientes desse período medieval, que chegou ao país por meio das legislações portuguesas. Vale ressaltar que, até o Código Civil de 1916, as Ordenações Filipinas eram a fonte de aplicação do direito brasileiro. O primeiro Código Civil brasileiro, elaborado em 1916 e que entrou em vigor a partir de 1917, regulamentou o aforamento, mantendo, apesar de determinadas modificações, muitas das determinações vigentes nas Ordenações ${ }^{7}$.

Said Júnior destacou, portanto, que, no século XIX, o desejo de modernização jurídica verificado no contexto brasileiro do período chocou-se com tradições remotas herdadas da antiga metrópole e incorporadas ao direito nacional. Assim, o direito aplicado no Brasil convivia com um conjunto de ideias jurídicas novas, provenientes de lugares em que ocorreram revoluções liberais, mas ainda não possuía um código, permanecia sendo regulamentado pelas Ordenações Filipinas. Tratava-se de uma relação ambivalente, formas novas de encarar a propriedade convivendo com modelos tradicionais (JÚNIOR STAUT, 2009, p.20) ${ }^{8}$.

Ao leitor pode parecer estranho retomar aspectos da legislação portuguesa vigente no Brasil ainda no período colonial para explicar um instituto que ainda vigorava no início do século XX em Natal, capital de um pequeno estado da república brasileira ${ }^{9}$. Entretanto, este artigo compartilha das concepções de Paolo Grossi sobre o

\footnotetext{
${ }^{7}$ Antes do Código Civil de 1916, o Decreto n. 1.318 de 30 de janeiro de 1854, que mandou executar a Lei de Terras de 1850, já havia mantido e regulamentado tal instituto. O artigo $79^{\circ}$ do Regulamento de 1854 mantinha o foro e o laudêmio (valor pago ao senhorio após as alienações). Ver: DECRETO número 1.318 de 30 de janeiro de 1854. In: BRASIL, Ministério Extraordinário para Assuntos Fundiários. Coletânea: legislação agrária, legislação de registros públicos, jurisprudência. Brasília: Assuntos Fundiários, 1983.

${ }^{8}$ Said também comentou as influências advindas de países que sofreram revoluções liberais, sobretudo a proveniente do Code Civil também denominado de Código de Napoleão, elaborado após a Revolução na França. Segundo o autor, o código é a grande marca da nova mentalidade jurídica. Todavia, o próprio código francês demonstrou continuidade com o período anterior, ao expressar em seu artigo $544^{\circ}$ que a propriedade era um conjunto de poderes de gozar e dispor das coisas, remetendo, assim, à antiga mentalidade de uma propriedade dividida (herança da concepção de propriedade do medievo). Ver ainda artigo de Rosa Congost que analisou alguns códigos de países que sofreram revoluções liberais e observou a presença da mentalidade proprietária dos domínios divididos: (CONGOST, 2000, p.61-93).

${ }^{9}$ Segundo Grossi, esse estranhamento teria como causa o reducionismo jurídico provocado desde o período de formação do Estado Moderno, que teria encolhido-se em um constrangedor horizonte de URBANA, V.6, no 9, ago-dez, 2014 - Dossiê: Dimensões Simbólicas das Intervenções Urbanas CIEC/UNICAMP
} 
significado das propriedades. Para o autor, propriedade é antes de tudo mentalidade, não pode jamais constituir-se somente em uma mera regra técnica, sendo sempre

Uma resposta ao eterno problema da relação entre homens e coisas, da friç̧ão entre mundo dos sujeitos e mundo dos fenômenos, e aquele que se propõe a reconstruir sua história, longe de ceder a tentações isolacionistas, deverá, ao contrário, tentar colocá-la sempre no interior de uma mentalidade e de um sistema fundiário com função eminentemente interpretativa (GROSSI, 2006, p.16).

Assim, Grossi entende que não existe apenas um único modelo de propriedade, já que ela é fruto da mentalidade da sociedade de determinado período. Para o autor, essas mudanças de mentalidades são lentas, atuam na esfera da longa duração. As paisagens e as ordens sociais podem sofrer alterações, mas uma mesma mentalidade pode persistir durante muitos séculos. Foi o que, segundo Grossi, ocorreu com a mentalidade proprietária medieval, caracterizada pela divisão dos domínios. Mesmo com a configuração do que o autor denominou de mentalidade proprietária moderna, aquela marcada pela simplicidade, abstração e pleno vínculo com um indivíduo, os valores proprietários medievais permaneceram, levando consigo suas ambivalências, contradições e incertezas (GROSSI, 2006, p.33).

Dessa maneira, para analisar a mentalidade proprietária da capital norte-riograndense no início do século XX é necessário, pois, tecer esse comentário sobre a influência da mentalidade proprietária do medievo, caracterizada pela divisão dos domínios, que muito influenciou o instituto do aforamento urbano vigente na realidade natalense. Também se torna essencial discutir como a mentalidade proprietária moderna, que começou a estabelecer-se com mais força em meados do século XIX, conviveu com permanências da mentalidade proprietária anterior, para, em seguida, mostrar como essas mentalidades atuaram nas relações entre foreiros e Intendência ${ }^{10}$.

modelos, sacrificando a complexidade da experiência jurídica. Para o autor, o direito é espelho da sociedade, reflete sua estrutura variada, estratificada e diferenciada, não pode ser entendido apenas como uma realidade simples e unilinear, ver: (GROSSI, 2007, p. 68; 58-59).

${ }^{10}$ É válido ressaltar que alguns autores e juristas não consideram o aforamento enquanto um tipo de propriedade, já que esse instituto pressupõe a divisão dos domínios (útil e direto). Esses juristas alegam que o direito não admite a divisão da propriedade. Entretanto, deve-se ressaltar que esses autores estão analisando o aforamento na contemporaneidade, nas determinações do Código Civil de seus períodos contemporâneos - seja o de 1916 para as publicações de juristas anteriores a 2002 ou o de 2002 para as publicações mais recentes. De acordo com as concepções de Paolo Grossi, esses juristas estariam cometendo o que o autor denominou de "absolutismo jurídico", sacralizando a concepção proprietária vigente na sua contemporaneidade - a propriedade moderna - e tentando torná-la absoluta, encaixá-la em realidades diferenciadas. Segundo Grossi, não se deve vendar os olhos e considerar exclusiva uma paisagem jurídica apenas pela razão simplista de que ela está próxima e é familiar. Não se pode URBANA, V.6, no 9, ago-dez, 2014 - Dossiê: Dimensões Simbólicas das Intervenções Urbanas CIEC/UNICAMP 
Assim, observa-se que elementos presentes nas Ordenações Filipinas que regulavam as questões civis do Brasil desde o período colonial também podem ser encontrados nas legislações que regulamentaram o aforamento do solo urbano no bairro Cidade Nova durante a Primeira República. Aforamentos em Natal existiram desde o período colonial, e, para a região de Cidade Nova começaram a ser instituídos em 1903, antes do Código Civil, por isso a necessidade do recuo e de explicações que possam reconstruir essa mentalidade marcada por diferentes concepções proprietárias.

As Ordenações Filipinas passaram a vigorar em Portugal por volta de 1603, sucedendo às Ordenações Afonsinas e às Ordenações Manuelinas ${ }^{11}$. Entre as determinações sobre o aforamento presentes no Livro Quarto das Ordenações Filipinas, algumas merecem destaque por terem permanecido, apesar de determinadas mudanças, nas legislações estaduais e locais de várias partes do Brasil, entre essas o Rio Grande do Norte. O Título XXXVIII desse livro determinou ser possível alienar o objeto da enfiteuse, isto é, vender a terra aforada a outrem. Entretanto, não se tratava da venda como se conhece na atualidade, que marca o processo de transação da propriedade moderna, em que o indivíduo paga uma quantia e adquire a propriedade plena da terra.

Em relação ao aforamento, o que se vendia era o direito de tornar-se foreiro, acompanhado por determinadas obrigações características do instituto. O foreiro inicial repassava, em troca de determinada quantia, o domínio útil do terreno para um segundo indivíduo, que teria que continuar honrando suas obrigações de foreiro. 0 primeiro foreiro deveria avisar ao senhorio que pretendia alienar a terra e pagar ao mesmo uma taxa de transferência, denominada laudêmio.

Outro título das Ordenações Filipinas que influenciou as legislações brasileiras posteriores sobre a enfiteuse foi o XXXIX. Segundo tal título, o foreiro que deixasse de

considerar única aquela que é simplesmente uma solução histórica dominante. Grossi defendeu, portanto, a necessidade da pluralização proprietária, ou seja, para o autor, os juristas e historiadores do direito devem relativizar, historicizar as propriedades, compreendendo que existem tantas propriedades quantas são as experiências jurídicas que se sucederam no tempo. Assim, segundo Grossi, o aforamento pode sim ser considerado uma forma de propriedade, pois os domínios (útil e direto) são sempre uma resposta à procura daquele momento mais intenso do pertencimento, são, pois, a tradução de uma determinada mentalidade. Para uma discussão mais aprofundada sobre essa temática, ver: (GROSSI, 2006, p.55-56).

${ }^{11}$ As Ordenações Filipinas eram formadas por cinco livros. As disposições sobre as regras para aforamento de terrenos foram regulamentadas no Livro Quarto. Para mais informações sobre as Ordenações do Reino e, principalmente sobre as Ordenações Filipinas, ver: CóDIGO Filipino ou Ordenações e Leis do Reino de Portugal: recompiladas por mandado d'el-Rei Dom Felipe I. Ed. Fac. - similar da $14^{\circ}$ ed. de 1821. In: (ALMEIDA, 2004,p.xix-xxviii).

URBANA, V.6, no 9, ago-dez, 2014 - Dossiê: Dimensões Simbólicas das Intervenções Urbanas CIEC/UNICAMP 
pagar o foro durante três anos perderia o direito que tinha sobre o terreno, deixando de possuir, portanto, o domínio útil do mesmo. Ao não pagar o foro anual, o enfiteuta entrava em comisso. Contudo, vale ressaltar que nem sempre o que estava na lei era respeitado na prática. Deve-se atentar para as dificuldades de fiscalização dessas obrigações, e para o fato de que em muitos casos não seria lucrativo para o senhorio rescindir o contrato enfitêutico.

No Brasil, desde o período colonial, o instituto do aforamento foi aplicado e regulamentado pelas câmaras de vilas e de cidades ${ }^{12}$. Quando uma aglomeração recebia foros de vila ou de cidade, a Coroa doava uma gleba de terras, que passava a ser denominada rossio e constituía os bens dessas localidades. Uma parte dessas terras era destinada às plantações comunais e outra poderia ser parcelada e concedida aos habitantes por meio de contratos enfitêuticos (FONSECA, 2011, p.30). Nesses casos, as câmaras eram as detentoras do domínio direto dos terrenos, enquanto os moradores possuíam o domínio útil. O pagamento dos foros anuais e dos laudêmios auxiliava nas receitas locais e, em algumas localidades, representava as maiores fontes de recurso das câmaras.

Esse processo de concessão de terrenos por parte da câmara aos moradores com base em contratos enfitêuticos não era sempre realizado de modo pacífico, pois existiram diversos conflitos que envolveram esse processo de acesso à terra. Em relação à Câmara de Natal, Rubenilson Teixeira elucidou que, por ter tido a condição de cidade logo após a sua fundação, a Câmara de Natal possuiu rossio desde 1605, conforme foi registrado no documento sobre a repartição de terras do Rio Grande de $1614^{13}$. Teixeira também ressaltou que o processo de instituição das câmaras e de seus patrimônios fundiários no Rio Grande do Norte gerou conflitos ao longo do tempo, tanto entre câmara e proprietários individuais como em relação à Igreja. O autor procurou analisar os conflitos existentes entre o poder eclesiástico e o poder público, não se dedicando à análise da concessão de terras das câmaras a particulares

\footnotetext{
${ }^{12}$ A cobrança do foro também foi instituída para sesmarias, por meio da ordem régia de 20 de janeiro de 1699. Contudo, a cobrança dessa nova taxa foi restrita às capitanias do norte do Estado do Brasil: Pernambuco, Paraíba, Ceará e Rio Grande. Para mais detalhes sobre essa cobrança, ver: ALVEAL; DANTAS, 2013, p.1-4).

${ }^{13}$ Segundo Teixeira, nesse documento foi encontrado o registro da data de terra n.76, concedida pelo capitão-mor Jerônimo de Albuquerque à câmara local em 1605. Rubenilson Teixeira também destacou que os autores que discorreram sobre o tamanho do rossio da cidade apontaram extensões diferentes. Alguns elucidaram que se tratava de um terreno de 6.666 metros e outros destacaram o tamanho de duas léguas de comprimento por meia légua de largura, ver: (TEIXEIRA, 396).

URBANA, V.6, no 9, ago-dez, 2014 - Dossiê: Dimensões Simbólicas das Intervenções Urbanas CIEC/UNICAMP
} 
por meio de contratos enfitêuticos ${ }^{14}$. Entretanto, apesar de não ter analisado essa questão, o trabalho de Teixeira torna-se importante no diálogo sobre o instituto do aforamento por ter destacado como esse instituto também foi utilizado pela Igreja, grande detentora de terras urbanas em várias vilas e cidades do então Rio Grande.

Apesar das pressões sofridas, Teixeira destacou que a Igreja conseguiu manter a propriedade de algumas terras urbanas no século XX e no século XXI. Em cada localidade a posse e a exploração desse patrimônio revelou-se de maneira distinta. $O$ controle da Igreja sobre sua propriedade fundiária dependia do interesse que os representantes locais dedicavam e ainda dedicam a tal questão. O autor observou como, em pleno século XXI, ainda existem contratos enfitêuticos em cidades do Rio Grande do Norte, como em Mossoró e Assú. Nessas cidades, a Igreja continua concedendo terras em troca do pagamento de foro anual.

Pode-se observar, após a análise do estudo de Teixeira, como a mentalidade proprietária moderna, baseada na construção de mercados de terras especulativos, em que casas e terrenos são vendidos e o novo proprietário tem pleno poder sobre o patrimônio que adquire, conviveu e ainda convive com a mentalidade proprietária característica do medievo, que pressupõe a divisão dos domínios. Teixeira também observou que em vários municípios do Rio Grande do Norte o foro caiu em desuso. Nesses municípios, quando um determinado habitante deseja vender a um terceiro sua casa situada em terras eclesiásticas aforadas, a negociação efetua-se normalmente, seguindo os princípios do mercado impessoal, desde que o foreiro vendedor respeite o pagamento do laudêmio à Igreja, que, nesse caso, é o senhorio, detentora do domínio direto da terra. Assim, nota-se como o instituto do aforamento acabou sendo incorporado pela lógica do mercado impessoal, participando, ao lado da propriedade moderna, de transações lucrativas economicamente.

Não se pode pensar que o instituto do aforamento, que tem como princípio básico a divisão dos domínios, permaneceu em uma sociedade capitalista e marcada por interesses especulativos conforme foi elaborado para uma sociedade do período

\footnotetext{
${ }^{14}$ Ao longo da pesquisa não foram encontrados estudos locais (para municípios do Rio Grande do Norte) que analisassem a concessão de terras urbanas por meio de contratos enfitêuticos. Esses estudos não foram encontrados nem em relação ao período colonial nem para qualquer outro período. $O$ estudo de Teixeira foi o único que mencionou o aforamento urbano para cidades do Rio Grande do Norte. Outro estudo que merece ser destacado é a monografia de Carlos André Souza. Souza trabalhou questões relacionadas ao aforamento de terrenos da marinha entre 1831 e 1889. Entretanto, vale ressaltar que os terrenos de marinha possuíam toda uma legislação específica, não sendo regulamentados pelas mesmas leis que regulavam o aforamento de terras do patrimônio municipal, àquelas advindas do rossio. Ver: (SOUZA, 2012).
}

URBANA, V.6, no 9, ago-dez, 2014 - Dossiê: Dimensões Simbólicas das Intervenções Urbanas CIEC/UNICAMP 
feudal. Adaptações foram realizadas. Da mesma forma que a propriedade moderna, perfeita e plena, não deve ser sacralizada, compreendida enquanto única forma de acesso à terra, o aforamento urbano não deve ser analisado como imutável, mas sim trabalhado em cada período de acordo com suas especificidades.

No período imperial, segundo Laura Beck Varela, tem-se duas legislações que podem ser consideradas marcos no processo da passagem da propriedade dividida ou condicionada para a forma jurídica absoluta e individual: a Lei de Terras de 1850 e a Lei n.1237, de 24 de setembro de 1864, mais conhecida como Lei Hipotecária. Todavia, a autora não considerou que as mudanças provocadas por essas leis foram radicais e repentinas, também destacando as continuidades e contribuindo para desfazer, assim como Grossi, o mito da naturalidade da propriedade moderna, mostrando como essa propriedade tem vida recente e foi fruto de um processo complexo (VARELA, 2005, p.10).

Para Varela, a Lei de Terras teve como uma das suas motivações a introdução no país de relações capitalista de produção, visando também separar o público do privado, firmando as bases para a regularização da propriedade privada no Brasil e para o afastamento da fórmula jurídica condicionada por deveres como o cultivo, característica do sistema de distribuição de sesmarias ${ }^{15}$. Já a Lei Hipotecária de 1864 procurou romper com o regime das hipotecas ocultas, e uma das suas principais contribuições foi determinar não somente o registro das hipotecas, mas também a transcrição dos títulos de transmissão de qualquer imóvel.

Dessa maneira, a lei instituía um sistema que divulgava o estado atual das propriedades, evitando fraudes e estelionatos. O registro garantia que uma mesma propriedade não fosse hipotecada por sujeitos diferenciados, que um sujeito não

\footnotetext{
${ }^{15}$ Muitos autores que comentam a Lei de Terras reduzem suas interpretações apenas ao primeiro artigo dessa lei, destacando que, após essa legislação, a terra poderia ser adquirida somente por meio da compra. Todavia, deve-se asseverar que a Lei de Terras, bem como seu regulamento promulgado em 1854, apresentou diversos artigos que, entre outros regulamentos, dispuseram sobre a regularização de posses e a permissão para a continuidade dos aforamentos. Segundo Motta, a Lei de Terras não foi criada apenas para resolver o problema da mão-de-obra ou para impedir a possibilidade de colonos estrangeiros terem fácil acesso à terra. Essa lei, como toda legislação, teve uma historicidade, um contexto, uma racionalidade de produção. Em seu livro, Motta demonstrou como na Câmara dos Deputados e no Senado existiram ferrenhas discussões e como a Lei de Terras foi fruto das ambiguidades dessas discussões, expressão das percepções diversas sobre os diferentes costumes e concepções em relação ao processo de apropriação da terra. A autora também destacou, por meio de exemplos, como a referida lei podia ser apropriada pelas camadas menos abastadas, como os lavradores, não servindo apenas para legitimar o poder dos grandes latifundiários, ver: (MOTTA, 2008). Dessa maneira, não se deve reduzir a interpretação da Lei de 1850 ao seu primeiro artigo, nem pensar que a modificação por ela instituída foi instantânea. Como já elucidado, as políticas de apropriação do solo urbano não foram modificadas de forma automática após a promulgação da Lei de 1850, um exemplo disso é a política de aforamento urbano existente em vários estados brasileiras ainda na atualidade.
}

URBANA, V.6, no 9, ago-dez, 2014 - Dossiê: Dimensões Simbólicas das Intervenções Urbanas CIEC/UNICAMP 
hipotecasse uma propriedade que já tivesse transmitido a outrem, entre outros casos. A transcrição seria elemento indispensável para que os títulos de propriedade tivessem efeito perante terceiros.

Segundo Varela, a Lei Hipotecária de 1864 foi um dos principais institutos jurídicos em prol da circulação da riqueza, "na medida em que possibilita constituir a propriedade imobiliária garantia de crédito nas transações"(VARELA, 2005,p.174). A Lei Hipotecária também influenciou o processo de elaboração do Código Civil de 1916, que efetivamente criou o registro de imóveis em sentido amplo, aproveitando o registro geral organizado em virtude da reforma hipotecária de 1864. Assim, a transcrição dos títulos passou de mera formalidade, complementar à legislação hipotecária, a verdadeiro modo de aquisição da propriedade, contribuindo para o processo de transição de uma mentalidade proprietária baseada em domínios divididos e formas de condicionamento, a uma mentalidade proprietária absoluta, abstrata, pertencente a um único indivíduo.

Todavia, mesmo com essas mudanças nas leis que regulavam o processo de apropriação da terra no país, o instituto do aforamento urbano e outras formas de apropriação tradicionais continuaram existindo. No período imperial, apesar de as câmaras municipais terem sido transformadas em corpos administrativos de poder restrito, os direitos seculares referentes aos terrenos que constituíam o antigo rossio permaneceram. As câmaras municipais continuaram legislando e fiscalizando o processo de aforamento, de arrendamento e aluguel de bens, bem como mediando os procedimentos de venda e troca. Os rendimentos obtidos com essas transações eram utilizados para as melhorias urbanas e pagamentos de custos administrativos (GLEZER, 2007, p.92).

A pesquisa realizada nos livros de leis provinciais do Rio Grande do Norte constatou que durante o período imperial os foros dos patrimônios municipais, bem como os laudêmios obtidos com a alienação dos mesmos, faziam parte das receitas municipais da província, conforme exposto no artigo 270 da Lei n. 857 de 1882 (RIO GRANDE DO NORTE, 1882, p.27-43).

Os códigos de posturas de Natal também demonstraram a utilização da enfiteuse no processo de apropriação do solo da cidade durante o Império. A Lei n. 823, de 11 de dezembro de 1877, que determinou o código de posturas da cidade, apresentou, logo no primeiro capítulo, as regras para a concessão de terras por meio de contratos enfitêuticos. A lei determinava que nenhum indivíduo poderia fazer roçados e construir sítios sem licença da câmara municipal, que deveria conceder URBANA, V.6, no 9, ago-dez, 2014 - Dossiê: Dimensões Simbólicas das Intervenções Urbanas CIEC/UNICAMP 
título de aforamento. Esses títulos eram concedidos pelo presidente da Câmara, e neles seriam registrados o tamanho do terreno e o preço de foro a ser cobrado anualmente.

O código de posturas também elucidava que deveria existir um livro especial para registrar as cartas de foro que seriam expedidas pela municipalidade e os processos de transferências. Os terrenos concedidos em aforamento deveriam ser demarcados, alinhados e nivelados. O foro deveria ser cobrado na razão de 20 réis por metro quadrado, valor pago anualmente. Caso o foreiro não fechasse ou não edificasse o terreno no prazo de um ano, deveria pagar entre 10.000 a 20.000 réis de multa, podendo ainda entrar em comisso e perder o direito útil dos terrenos concedidos em enfiteuse (RIO GRANDE DO NORTE, 1882, p.62-63).

A Lei n. 823 também determinava que o laudêmio deveria ser calculado na razão de $2,5 \%$ em relação ao preço cobrado pelo foreiro na alienação do terreno. Nota-se como o instituto era regulamentado pelo poder local, indicando a preocupação da Câmara em garantir que os foreiros pagassem corretamente o foro anual, que era fundamental na receita do poder local.

Com a proclamação da República tem-se nova política de apropriação da terra. Em 1891 foi elaborada a primeira Constituição do Brasil republicano, determinando que as terras públicas passariam a ser propriedade dos estados em que estivessem situadas e que cada unidade da federação poderia legislar à sua maneira em relação à discriminação das terras devolutas e no tocante à revalidação de sesmarias e legitimação de posses, embora devessem respeitar os princípios básicos da Lei de 1850 e de seu regulamento publicado em 1854. As leis estaduais que regulamentaram as formas de acesso a essas terras públicas também ficaram conhecidas como leis de terra estaduais (SILVA, 2011).

No Rio Grande do Norte, a lei que determinou a nova política de acesso às terras estaduais foi a Lei n.81, de 09 de setembro de 1895, cujo regulamento foi publicado no jornal A Republica em 03 de dezembro de 1895 e no dia 05 de janeiro de 1896 (GOVERNO do Estado, 1895, 05 jan. 1896). Essa lei estadual reafirmava alguns princípios existentes na Lei de Terras de 1850. Segundo a lei de terras do Rio Grande do Norte, as terras estaduais poderiam ser adquiridas por compra e aforamento, e dava-se a chance de regularização de posses. Os terrenos que tivessem sido apossados há mais de trinta anos e que apresentassem cultura e morada do posseiro poderiam ser legitimados. As sesmarias que cumprissem função de cultura e moradia também podiam ser revalidadas. A lei estabelecia um prazo para que essas terras URBANA, V.6, no 9, ago-dez, 2014 - Dossiê: Dimensões Simbólicas das Intervenções Urbanas CIEC/UNICAMP 
fossem registradas, iniciado seis meses após a promulgação da referida lei.

Entretanto, vale ressaltar que, assim como a Lei de Terras nacional, a Lei de Terras estadual de 1895 também sofreu resistência e não foi bem aceita e praticada pelos possuidores de terras do Rio Grande do Norte. O prazo para registro de terras foi prorrogado nos seis anos que se seguiram à promulgação da referida lei (MONTEIRO, 2007, p.34). Posseiros, sesmeiros e foreiros deixavam de registrar suas terras, processo que traduzia uma estratégia desses proprietários, que poderiam expandir seus terrenos, realizar subenfiteuses em terras que, caso registradas, estariam fora de seus patrimônios, e ainda poupariam o dinheiro que seria dispensado com o processo de medição e de registro.

Em dezembro de 1915 foi promulgada a Lei n.396, que substituiu a Lei de 1895. Essa nova lei de terras do Rio Grande do Norte foi regulamentada apenas em 1918 (RIO GRANDE DO NORTE, 1916, 26 MAR. 1918). Observa-se como as legislações sobre formas de apropriação de terras estaduais não eram respeitadas, sendo necessárias revisões que, por sua vez, eram demoradas e acabavam afastandose das determinações presentes na Lei de Terras de 1850, elaborada há mais de 65 anos.

Conforme ressaltou Denise Monteiro, as duas leis estaduais, tanto a de 1895 como a de 1915, destacaram a possibilidade do reconhecimento de posses ocorridas entre 1854 e 1888, ou seja, posses estabelecidas durante todo o período do Segundo Império poderiam ser ainda consideradas legítimas. Entretanto, a Lei de 1850 já tinha proibido a legitimação de posses estabelecidas a partir de 1854. Assim, é possível notar como as leis de terras do Rio Grande do Norte não cumpriram o estabelecido na Constituição de 1891. Como visto, segundo essa Constituição de 1891, as políticas estaduais de terras deveriam respeitar os princípios básicos da Lei de 1850 e de seu regulamento de 1854, fato que não ocorreu com a política de terras do Rio Grande do Norte, em que as duas leis locais afastaram-se das prerrogativas estabelecidas pela lei de terras nacional, beneficiando a condição de posseiro.

Esse emaranhado de leis sendo promulgadas, revogadas e reformadas pode resultar no que Holston denominou de "processo de legalização de atos ilegais" (HOLSTON, 1993). Essa teia complicada de leis regulamentando as políticas de terras nacionais e estaduais gerou um processo de confusão jurídica, que foi, segundo o autor, característico de todo o sistema jurídico brasileiro. Trata-se de um sistema que não é somente fruto de corrupção, incompetência e manipulações individuais. Para Holston, o sistema jurídico incorporou e incorpora intenções de perpetuar as URBANA, V.6, no 9, ago-dez, 2014 - Dossiê: Dimensões Simbólicas das Intervenções Urbanas CIEC/UNICAMP 
irresoluções por meio das complicações legais, facilitando os estratagemas e a fraudulência, ou seja, "os princípios da lei no Brasil produzem, sistematicamente, irresoluções para uma sociedade na qual a irresolução é um princípio de ordem" (HOLSTON, 1993, p.10).

Para Holston, o sistema jurídico brasileiro é fruto dessa tradição desestabilizadora, não tendo como objetivo real resolver conflitos de terra de maneira justa, nem decidir sobre seus méritos legais por meio de procedimentos judiciais. De acordo com o autor, a Lei de Terras de 1850 foi representativa desse processo, sendo confusa, indecisa e disfuncional. Essa confusão na legislação brasileira em geral foi e é responsável por conflitos irresolúveis nas disputas de terras, culminando com a legalização de algum tipo de usurpação.

Após a análise das leis de acesso à terra estadual promulgadas durante o período republicano, deve-se ressaltar a política de acesso às terras municipais, aquelas que constituíam o antigo rossio das câmaras. Com a República, as câmaras municipais foram dissolvidas e a gestão do patrimônio local passou a ficar a cargo dos conselhos de intendência. A Intendência de Natal foi estabelecida em 1890 e, ao longo de sua existência, publicou várias resoluções regulamentando o sistema de apropriação da terra por meio do instituto do aforamento.

\section{Estudando as (ir)resoluções municipais: o aforamento urbano em Natal e as especificidades desse instituto na apropriação de terrenos em Cidade Nova}

Ao analisar as leis estaduais e resoluções municiais sobre aforamento, bem como as cartas de aforamento do bairro Cidade Nova, verificou-se, em Natal e no Rio Grande do Norte, a existência de uma mentalidade proprietária ambivalente, compartilhando a contradição que Sérgio Said Junior apreendeu para o Brasil mesmo após a promulgação do Código Civil de 1916. Ao mesmo tempo em que existiam formas de acesso à terra por meio da simples venda para um indivíduo que possuía plenos poderes em relação ao terreno adquirido, caracterizando a concepção moderna de propriedade, simples e abstrata, a política de aforamento urbano também era uma realidade do período, responsável por parte considerável da receita da Intendência Municipal de Natal.

Nessa parte do estudo serão apresentadas algumas leis que regularam o instituto da enfiteuse, mas não se deve pensar que essas leis foram aplicadas tal qual instituído no papel. Os foreiros do terceiro bairro da cidade nem sempre cumpriam URBANA, V.6, no 9, ago-dez, 2014 - Dossiê: Dimensões Simbólicas das Intervenções Urbanas CIEC/UNICAMP 
essas regras, utilizando as brechas e irresoluções de algumas para integrarem-se a um mercado especulativo ou visando fortalecer laços políticos e pessoais que renderiam outros tipos de capitais além do econômico.

Em relação às regras para cálculo do foro a ser cobrado pelos terrenos concedidos em enfiteuse, ao longo do início do século XX existiram diversas resoluções estabelecendo modificações nas formas de realização desse cálculo. É válido ressaltar ainda que a cobrança de foro também dependia, além do tamanho do terreno, da área em que ele estava localizado. Geralmente, para a área urbana, o foro anual era caracterizado por um valor inferior ao estipulado para áreas suburbanas, conforme foi analisado por meio dos estudos das resoluções publicadas até a década de 191016.

Apesar de não ter sido encontrada nenhuma resolução ou matéria de jornal que justificasse esse critério na forma de calcular os foros anuais, é possível conjecturar que essa diferença ocorria porque o foreiro do perímetro urbano tinha obrigações mais dispendiosas do que o foreiro da área suburbana. Nos terrenos suburbanos, os foreiros não eram obrigados a construir edificações em um determinado prazo após a concessão da terra, como ocorria na área urbana. A própria Resolução n.55 demonstrou a necessidade de edificação nas terras foreiras de Cidade Nova, bairro urbano da capital. Fora da área urbana, os foreiros deviam apenas cercar as terras aforadas e, a longo prazo, estabelecer cultivo (A REPUBLICA, 25 jan. 1912). Talvez por isso o cálculo para aforamento na área urbana fosse menos dispendioso, incentivando o enfiteuta, que logo teria que custear uma edificação.Diferentemente do foreiro de áreas suburbanas, que, para cumprir a legislação, gastava apenas uma quantia insignificante para cercar os terrenos.

A primeira resolução publicada em 1903 que estabeleceu regras para calcular o preço do foro foi a Resolução n.73 (A REPUBLICA, 11 fev. 1903). Segundo essa lei, os foros dos terrenos compreendidos na área urbana seriam calculados na razão de cinco réis por metro quadrado de superfície. Em relação ao processo de cobrança de foro, essa legislação municipal ressaltou que eles seriam cobrados mediante recibos por semestres vencidos. Além de definir as regras para cobrança do foro anual, a Resolução n.73 ainda determinou a criação de três livros especiais, um para cada bairro urbano, nos quais seriam registradas as cartas de aforamento expedidas. 0 processo de expedição de carta de aforamento não era gratuito. 0 artigo $8^{\circ}$ da

${ }^{16}$ Contudo, na década de 1920 , observa-se que os terrenos da área suburbana terão valores superiores aos da área urbana.

URBANA, V.6, no 9, ago-dez, 2014 - Dossiê: Dimensões Simbólicas das Intervenções Urbanas CIEC/UNICAMP 
referida lei destacou que, além de pagar o preço do selo ${ }^{17}$ e mil réis pela cordeação, processo de alinhamento e medição de terras com o uso de cordas, o enfiteuta ainda deveria pagar pela carta uma importância que variava de 5.000 a 20.000 réis dependendo da superfície em metros quadrados do terreno concedido.

Essa lei também determinou algumas regras que deveriam ser respeitadas durante o processo de alienação do domínio útil de terras municipais aforadas. Como já comentado, os terrenos aforados podiam ser alienados, conforme exposto desde as Ordenações Filipinas, em seu título XXXVIII. A Resolução n.73 destacou que a Intendência de Natal deveria expedir licenças para autorizar os processos de transferência de terrenos pertencentes ao seu patrimônio. A autorização para a alienação ocorreria mediante a exibição da carta de aforamento do terreno que se pretendia transferir. A lei também ressaltou que, sempre que a transferência não se referisse à totalidade do terreno constante na carta de aforamento, essa carta deveria ser recolhida ao arquivo e outras deveriam ser expedidas, de acordo com a quantidade de novos foreiros resultante do processo de alienação.

Dessa maneira, as novas cartas expedidas pelo poder municipal registrariam o nome do novo foreiro e o novo preço de foro a ser cobrado, referente àquela parcela de terra desmembrada da área original. Por esse processo de expedições de novas cartas deveria ser pago, além do preço do selo, 1.000 réis de emolumentos por cada nova carta expedida. Nota-se, portanto, que era obrigação da Intendência, durante os processos de alienação do direito de tornar-se foreiro, recolher a antiga carta de aforamento e expedir novas, registrando as informações dos novos enfiteutas.

É importante reforçar que o processo de transferência de terras aforadas não é o mesmo que ocorre com a propriedade no sentido moderno, aquela pertencente diretamente a um único indivíduo, que pode dispor plenamente da mesma. No caso estudado os terrenos da Intendência de Natal respeitavam a mentalidade proprietária que também tinha como cerne a ideia dos domínios divididos. O foreiro, aquele que possuía o domínio útil, não vendia a propriedade plena da terra aforada, pois ele não a possuía. A Intendência era, e continuaria sendo mesmo após várias alienações, a detentora do domínio direto desses terrenos. Por isso, ao alienar a outrem, o foreiro inicial deveria pedir permissão e pagar ao poder público uma taxa, o laudêmio, uma espécie de indenização por estar transferindo, por necessidade ou objetivando obter lucros, o patrimônio público. O comprador, por sua vez, seria o novo foreiro, o que passaria a deter o domínio útil das terras, devendo, portanto, continuar pagando o

${ }^{17}$ Essa resolução não informou o valor a ser cobrado pela expedição do selo.

URBANA, V.6, no 9, ago-dez, 2014 - Dossiê: Dimensões Simbólicas das Intervenções Urbanas CIEC/UNICAMP 
foro anual à Intendência, por estar usufruindo dessas terras.

Pode ser difícil para o leitor compreender essa mentalidade proprietária, uma vez que, na atualidade, a presença desse instituto é muito rara. Os anúncios publicados no A Republica e no Diário do Natal podem também ter contribuindo para essa confusão. Muitos anúncios que destacavam a venda de propriedades não explicitavam que o que se vendia era o domínio útil e não a propriedade plena, como pode ser observado nos dois exemplos que seguem:

Vende-se a propriedade onde mora o sr. Hermano Burity na Cidade Nova, desta capital; sendo uma morada de caza, um bom cercado com muitos pés de fructeiras e um poço com agua muito boa. A tratar com o mesmo Burity, [...] (A REPUBLICA, 14 abr. 1903).

Vende-se uma casa e um terreno anexo com 30 metros de frente e 90 de comprimento, com 22 pés de coqueiros, jaqueiras, cajueiros e goiabeiras, sito à Praça Pio $\mathrm{X}$, a tratar com Joaquim Emiliano Pereira do Lago, à rua 13 de Maio,n.41, Cidade Alta (A REPUBLICA, 16 set. 1910).

Como os textos acima destacados demonstram, os anúncios publicados nos periódicos eram, em sua maioria, bem simples, não mencionando que se vendia o direito de tornar-se foreiro e que, por exemplo, o indivíduo que comprasse a propriedade de Hermano Burity teria que continuar pagando o foro à Intendência. Aqueles que se interessassem pela casa e pelo terreno na praça Pedro Velho também teriam que honrar com as obrigações de foreiro. Possivelmente, a não menção ao instituto do aforamento nesses anúncios indicava que a mentalidade proprietária da capital no início do século XX tinha incorporado esse instituto.

Provavelmente, para os moradores da cidade naquele período, já estava implícito que as formas de apropriação na cidade lidavam com o aforamento, sobretudo em Cidade Nova, já que a própria resolução de criação desse bairro deixava explícito que a apropriação de terras seria por meio da enfiteuse. Assim, não era preciso explicitar no anúncio elementos que já tinham sido incorporados por aquela sociedade, que não thes eram estranhos.

Todavia, também foram publicados anúncios que, possivelmente na tentativa de atrair um maior número de interessados, ressaltavam como os terrenos e as casas a serem comercializados possuíam carta de aforamento e estavam com os pagamentos dos foros em dia. Esse foi o caso da matéria publicada em dezembro de 1907, anunciando a venda de um sítio com casa de vivenda na ruaMipibú, "cercado e legalizado com a carta de aforamento" (A REPUBLICA, 17 dez. 1907). Em dezembro de 1908, Maria dos Prazeres, por motivo de mudança de cidade, anunciou para venda URBANA, V.6, no 9, ago-dez, 2014 - Dossiê: Dimensões Simbólicas das Intervenções Urbanas CIEC/UNICAMP 
um terreno com carta de aforamento e foros pagos, cercado com arame farpado e possuindo três casinhas contiguas, que poderiam ser alugadas para terceiros. 0 terreno anunciado localizava-se entre a avenida Floriano Peixoto e a rua Trairi, nas proximidades da praça Pedro Velho (A REPUBLICA, 30 dez. 1908). Ao longo do período estudado foram encontrados poucos anúncios destacando que os terrenos eram aforados, a maior parte das propagandas não fazia menção direta à enfiteuse ${ }^{18}$.

Retornando à análise da Resolução n.73, é possível perceber como, com a publicação dessa lei em 1903, a Intendência Municipal demonstrou uma preocupação mais efetiva em regulamentar o instituto do aforamento urbano. Essa lei municipal, em seu artigo 50, destacou que, a partir de sua publicação, todos os ocupantes de terrenos municipais teriam seis meses de prazo para exibir na secretaria da Intendência as respectivas cartas de aforamento ou solicitá-las, caso não as possuíssem. Os foreiros que não respeitassem essa regra e não legalizassem suas ocupações em terrenos municipais sofreriam multa que poderia variar entre 50.000 a 100.000 réis.

O poder municipal tencionava, assim, regularizar a situação de muitos posseiros, que já ocupavam os terrenos de seu patrimônio, mas ainda não haviam regularizado essa ocupação por meio de contratos de aforamento, sendo, portanto, ocupantes inadimplentes, já que não tinham sido autorizados a dispor do domínio útil daquelas terras, prejudicando, ainda, a arrecadação municipal, já que não pagavam o foro anual.

Contudo, como já comentado, o sistema jurídico brasileiro é caracterizado pela incorporação constante de irresoluções e esse aspecto não deixou de ser observado nas resoluções publicadas pela Intendência de Natal. A existência de várias leis reafirmando um mesmo aspecto pode resultar em confusão jurídica, e, ao invés de servirem para regulamentar formas de apropriação da terra interessantes para a arrecadação pública, muitas irresoluções acabavam prejudicando a arrecadação municipal e favorecendo interesses privados. Assim, apesar de a Resolução n.73ter instituído o prazo de seis meses para a regularização das ocupações, a Intendência, em menos de um mês, publicou outra lei. Essa nova lei, ao estipular novas regras para a execução dessa regulamentação, acabou por estender o prazo de seis meses para a regularização dos terrenos municipais já ocupados.

A Resolução n.75, publicada em 03 de março de 1903, acrescentava um

\footnotetext{
18 São exemplos de anúncios que ressaltaram que os terrenos anunciados para vendas eram aforados: TERRENO na Cidade Nova. A Republica, Natal, 2 set. 1904; CASA. Diário do Natal, Natal, 29 nov. 1906. p.2; CASAS e terrenos à venda. A Republica, Natal, 23 jan. 1909. p.2; entre outros.

URBANA, V.6, no 9, ago-dez, 2014 - Dossiê: Dimensões Simbólicas das Intervenções Urbanas CIEC/UNICAMP
} 
detalhe que não foi mencionado pela Resolução n.73 (A REPUBLICA, 03 mar. 1903). O prazo de seis meses começaria a correr após uma publicação da Intendência, que deveria definir a numeração e os limites dos quarteirões de cada bairro urbano da cidade. Dessa maneira, a regra de seis meses para regulamentação começaria a valer somente para os terrenos ocupados na Ribeira, que já tinha tido seus quarteirões definidos desde o dia 16 de fevereiro. Já as regularizações para os bairros de Cidade Alta e Cidade Nova seriam, portanto, postergadas, até que seus quarteirões fossem plenamente definidos.

O texto da resolução n.75 é demonstrativo de como, até o início de 1903, as áreas e limites dos bairros de Natal não eram bem estabelecidos. Essa regularização começou a ser efetivada somente nesse período. De fato, apesar de a ideia de modernização, tão difundida na cidade pelos dirigentes locais desse período, ter sido caracterizada por um forte discurso de exaltação, essa preocupação com a regularização dos limites e numeração dos quarteirões também é capaz de demonstrar como essa modernização não ficou apenas restrita ao âmbito discursivo. A tentativa de definir com mais rigor os limites de cada bairro, o tamanho e a numeração de suas ruas, demonstrava também a intenção de imprimir uma gestão mais eficiente do patrimônio municipal, já que esse esquadrinhamento do espaço facilitaria o sistema de cobrança do foro e outros impostos municipais.

Ainda em 1903 foi publicada outra resolução versando sobre regras para estabelecer o preço dos foros anuais. Trata-se da Resolução n.81, que mantinha a base do cálculo estabelecido pela Resolução n.73, fazendo algumas alterações ( $A$ REPUBLICA, 15 set. 1903). Segundo a Resolução n.81, os foros de terrenos municipais nas áreas urbanas continuariam a ser cobrados à razão de cinco réis por metro quadrado, entretanto esse cálculo seria efetuado para um terreno de até $5.000 \mathrm{~m}^{2}$. O que excedesse de $5.000 \mathrm{~m}^{2}$ até $10.000 \mathrm{~m}^{2}$ seria calculado na razão de dois réis e o que ultrapasse os $10.000 \mathrm{~m}^{2}$ seria cobrado na razão de um réis ${ }^{19}$.

Em menos de um ano após a divulgação da Resolução n. 81, a Intendência de Natal publicou, a partir de maio de 1904, a Resolução n.92 que, como já elucidado no primeiro capítulo, tratava-se de uma extensa lei com vários capítulos, regulando inúmeras atividades do poder municipal, ratificando ou retificando diversas resoluções publicadas desde a criação da Intendência (A REPUBLICA, 14 maio-14 jun. 1904).

Sobre a questão do aforamento, a Resolução n.92 dedicou três longos

\footnotetext{
${ }^{19}$ Exemplo de cálculo: Se um terreno tivesse $16.000 \mathrm{~m}^{2}$ o cálculo seria realizado da seguinte forma: $5 \mathrm{x}$ 5.000 (cálculo até $5.000 \mathrm{~m}^{2}$ ) $+2 \times 5.000$ (o que excedeu de $5.000 \mathrm{~m}^{2}$ até $10.000 \mathrm{~m}^{2}$ ) $+1 \times 6.000$ (o que ultrapassou os $10.000 \mathrm{~m}^{2}$ ) $=41.000$ réis.

URBANA, V.6, no 9, ago-dez, 2014 - Dossiê: Dimensões Simbólicas das Intervenções Urbanas CIEC/UNICAMP
} 
capítulos regulamentando esse instituto na cidade. As normas para calcular o preço do foro anual foram novamente modificadas. Pela referida lei, os foros passavam a ser cobrados, na área urbana, na razão de cinco réis por metro quadrado de superfície, independente do tamanho do terreno. Talvez essa mudança tivesse como objetivo facilitar o processo de cobrança, evitando cálculos mais complicados. Já na área suburbana, o foro seria calculado na razão de trinta réis por metro quadrado. Observa-se que nesse período, como já comentado, os preços dos foros anuais dos terrenos das áreas suburbanas eram mais elevados.

Em relação ao preço a ser cobrado pela expedição de cartas de aforamento, a Resolução n.92 mantinha a mesma regra presente na Resolução n.73. No tocante ao processo de alienação de terrenos, a referida legislação também reforçava o texto da Resolução n.73, destacando que, após as transferências, deveriam ser expedidas novas cartas, com dados atualizados em relação ao novo foreiro, aos novos limites dos terrenos e à nova taxa anual a ser cobrada.

É importante frisar que as determinações para cálculo do foro estabelecidas pela Resolução n.92 vigoraram em Natal até o ano de 1916, quando nova resolução foi expedida, modificando o modelo estabelecido até então. A modificação ocorreu por meio da promulgação da Resolução n.194, publicada em 1916, que passou a vigorar até 1924, quando, novamente, a regra para o cálculo foi alterada. Ao longo da pesquisa o texto da Resolução n.194 não foi encontrado.

Contudo, foi possível observar que a Resolução n.194 alterou as formas de calcular o preço do foro por meio de outras matérias publicadas no $A$ Republica que fizeram referência a essa modificação ${ }^{20}$. Além disso, a Resolução n. 195, que fixou o orçamento da Intendência de Natal para o ano de 1917, publicada em dezembro de 1916, ressaltou que os foros da área urbana, naquele período, eram cobrados na razão de dez réis por metro quadrado e, na área suburbana, respeitavam o cálculo de trinta réis por metro quadrado (A REPUBLICA, 09 dez.-11 dez. 1916).

Nota-se como essa alteração dobrou o preço do foro a ser cobrado pelos terrenos do patrimônio municipal. Não foi encontrada nenhuma matéria de jornal ou texto de resolução que justificasse essa elevação nos preços dos terrenos. Contudo, pode-se conjecturar que essa elevação significaria uma maior valorização dessas terras, devendo-se, portanto, pagar mais pelo direito de usufruir do domínio útil das mesmas.Assim, com base na análise das resoluções até então comentadas, observa-

\footnotetext{
${ }^{20}$ Matérias da década de 1920 confirmaram essa modificação, ver: A REPUBLICA, Natal, 28 jun. 1923;A REPUBLICA, Natal, 09 jan. 1927; INTENDENCIA Municipal. A Republica, Natal, 14 jan. 1927; INTENDENCIA Municipal. A Republica, Natal, 20 jan. 1927, entre outras.

URBANA, V.6, no 9, ago-dez, 2014 - Dossiê: Dimensões Simbólicas das Intervenções Urbanas CIEC/UNICAMP
} 
se como a Intendência, em um período de aproximadamente um ano, publicou três resoluções estabelecendo três diferentes regras para calcular o preço do foro anual a ser cobrado por terrenos municipais aforados. Nota-se ainda como o modelo de cálculo instituído pela Resolução n.92 foi alterado somente em 1916. Abaixo segue uma tabela resumindo essas regras:

Tabela 1 - Regras para cálculo de foro em terrenos urbanos de acordo com as resoluções publicadas entre 1903-1916

Fonte: Tabela elaborada pela autora com base nas resoluções citadas

\begin{tabular}{|c|c|c|}
\hline $\begin{array}{l}\text { Período em que } \\
\text { começou a vigorar }\end{array}$ & Resolução & $\begin{array}{l}\text { Regra para cálculo de } \\
\text { foro }\end{array}$ \\
\hline 11 de fevereiro de 1903 & Resolução n.73 & $\begin{array}{c}5 \text { réis } \mathbf{X} \text { valor do } \\
\text { terreno em metros } \\
\text { quadrados }\end{array}$ \\
\hline 15 de setembro de 1903 & Resolução n.81 & $\begin{array}{c}5 \text { réis } \mathbf{X} \text { valor do } \\
\text { terreno em metros } \\
\text { quadrados até } \\
5.000 \mathrm{~m}^{2} \\
+ \\
2 \text { réis } \mathbf{X} \text { valor que } \\
\text { exceder de } 5.000 \mathrm{~m}^{2} \\
\text { até } 10.000 \mathrm{~m}^{2} \\
+ \\
1 \text { réis } \mathbf{X} \text { valor que } \\
\text { exceder de } 10.000 \mathrm{~m}^{2}\end{array}$ \\
\hline maio de $1904^{21}$ & Resolução n.92 & $\begin{array}{c}5 \text { réis } \mathbf{X} \text { valor do } \\
\text { terreno em metros } \\
\text { quadrados }\end{array}$ \\
\hline 28 de fevereiro de 1916 & Resolução n.194 & $\begin{array}{c}10 \text { réis } \mathbf{X} \text { valor do } \\
\text { terreno em metros } \\
\text { quadrados }\end{array}$ \\
\hline
\end{tabular}

Outros artigos da Resolução n.92 merecem ser analisados, já que foram responsáveis por regulamentar o processo de aforamento urbano de Natal durante quase todo o início do século XX. Como já ressaltado, os indivíduos que aforassem terras da área urbana teriam um prazo para construir edificações. Nota-se, portanto, que o objetivo principal da política de aforamento na área urbana da cidade era a construção de habitações, que eram escassas na capital. A Resolução n.55, que oficializou a criação de Cidade Nova, determinou que o prazo para edificar no bairro seria de três anos. A Resolução n.92, publicada em 1904, encurtou esse prazo, estabelecendo que os enfiteutas teriam apenas um ano, a ser contado a partir da data de expedição de suas cartas de aforamento, para estabelecer edificações nos terrenos

\footnotetext{
${ }^{21}$ Como já destacado, a resolução n.92 foi publicada em várias edições do jornal $A$ Republica do mês de maio de 1904, por isso optou-se por não destacar os dias da publicação na tabela elaborada.

URBANA, V.6, no 9, ago-dez, 2014 - Dossiê: Dimensões Simbólicas das Intervenções Urbanas CIEC/UNICAMP
} 
urbanos aforados. Caso os foreiros não cumprissem essa cláusula, o contrato enfitêutico poderia entrar em caducidade e o foreiro perderia o direito ao domínio útil da terra aforada.

Em relação ao processo de transferência do domínio útil de terrenos aforados, essa extensa resolução ratificou as normas já regulamentadas pela Resolução n.73. 0 foreiro que desejasse alienar a outrem o terreno aforado deveria informar à Intendência, que poderia ou não permitir a alienação. Em caso positivo, o foreiro inicial deveria pagar ao governo municipal, detentor do domínio direto dos terrenos, o laudêmio. Sobre as etapas para solicitar o aforamento, a Resolução n.92 determinou que o aspirante a enfiteuta deveria elaborar uma petição direcionada ao poder municipal. Após a entrega da petição, o auxiliar técnico e o fiscal da Intendência analisariam se o pedido era procedente e não estava modificando a planta da cidade.

Nota-se como essa resolução também foi responsável por criar um novo cargo na Intendência de Natal, o de auxiliar técnico do governo municipal. Segundo o artigo $15^{\circ}$ do capítulo II, esse funcionário receberia a gratificação mensal de 300.000 réis e poderia ser exercido efetivamente apenas por engenheiro ou agrimensor. Anteriormente a verificação dos terrenos era obrigação do próprio aspirante a foreiro, que deveria anexar junto a sua petição uma planta do terreno assinada por profissional. A Resolução n.79 tinha instituído que essa verificação não mais ficaria a cargo de um profissional escolhido pelo enfiteuta, mas sim de um engenheiro ou agrimensor escolhido pelo poder municipal. Em 1904, com a Resolução n.92, a Intendência novamente modificava essa prerrogativa, criando um novo cargo. Observa-se como a preocupação do poder local ficava cada vez mais expressiva. Era preciso ter uma maior garantia de que os terrenos concedidos em aforamento realmente possuíam a área alegada pelo foreiro, para que o pagamento do foro e, consequentemente, a receita da Intendência, não fosse prejudicado.

Após a verificação dos limites dos terrenos seria elaborado e divulgado um edital, para que os que se sentissem prejudicados fizessem suas reclamações. Esse edital seria fixado na porta do edifício municipal e publicado na imprensa. Apesar de algumas matérias já publicadas em 1900ter anunciado que já existiam solicitações de aforamento para Cidade Nova antes de sua oficialização (A REPUBLICA, 10 fev. 1900), editais que destacam requerimentos de aforamentos no terceiro bairro começaram a ser publicados no A Republica apenas a partir de 08 de janeiro de 1902, quatro dias após a publicação da Resolução n.55 que oficializou esse bairro.

Assim, por exemplo, o edital publicado em janeiro de 1902 estabelecia o prazo URBANA, V.6, no 9, ago-dez, 2014 - Dossiê: Dimensões Simbólicas das Intervenções Urbanas CIEC/UNICAMP 
de trinta dias para quem tencionasse reclamar da solicitação de Theodosio Paiva, que requeria em aforamento um terreno que possuía na Cidade Nova entre a praça Pedro Velho e a rua Mipibu (A REPUBLICA, Natal, 08 jan. 1902). Theodosio Ribeiro Paiva não era um habitante qualquer da capital. Em 1902 ele já integrava a Intendência Municipal de Natal, cargo que ocupou durante longo período, entre 1899-1910 e 1920-1922 (SANTOS, 2012, p.71). Paiva exerceu ainda a atividade de escriturário do Tesouro do Estado, era membro da Guarda Nacional (A REPUBLICA, 11 maio 1904) e grande acionista do Banco do Natal (A REPUBLICA, 06 fev. 1906). Como o texto do edital informa, o então intendente solicitava a regulamentação de um terreno que já possuía no terceiro bairro da cidade. Provavelmente, Theodosio Paiva tinha apossadose do terreno naquela área antes de sua oficialização.

O requerimento de Paiva demonstrou como indivíduos que trabalhavam na Intendência, a detentora do domínio útil daquelas terras, podiam aforar esses terrenos. De fato, ao longo da pesquisa, não foi encontrada nenhuma matéria ou lei que proibisse o aforamento de terras do patrimônio público por intendentes em exercício. Contudo, muitas vezes esses funcionários utilizavam seus cargos e descumpriam suas próprias leis nesse processo de estabelecimento de enfiteuses, demonstrando como as ideias republicanas de democracia, separação entre público e privado, preocupação com a coisa pública, entre outras, muitas vezes ficavam restritas apenas ao texto da lei. As ideias novas trazidas pela propaganda republicana conviviam com práticas tradicionais, marcadas pelo patrimonialismo, clientelismo e pessoalismo.

A maioria dos editais solicitando aforamentos publicados entre 1902 e 1919 requeria terras devolutas existentes no bairro Cidade Nova, ou seja, terras da Intendência que até então não tinham sido ocupadas e não eram usadas pelo poder público. Todavia, outros editais demonstraram, como foi o caso do edital em que Theodosio Paiva apareceu, que alguns aspirantes a enfiteutas já possuíam habitações, ranchos, casas, sítios, cercados, enfim, que já ocupavam de alguma maneira o terreno pretendido e desejavam, então, regularizar essas posses. Em março de 1906, por exemplo, o jornal A Republica publicou um edital no qual Suzana F. e Silva solicitava em aforamento um terreno em Cidade Nova, alegando que essa aspirante à foreira já possuía uma casa na terra almejada. Nesse mesmo edital, Januario Elias de Goes também solicitava aforamento de um terreno na rua Mossoró, onde possuía um rancho (A REPUBLICA, 06 mar. 1906).

Editais como esses podem ser indícios de que não eram somente membros URBANA, V.6, no 9, ago-dez, 2014 - Dossiê: Dimensões Simbólicas das Intervenções Urbanas CIEC/UNICAMP 
abastados e bem relacionados com o poder local que aforavam terrenos em Cidade Nova. Existiam indivíduos comuns sobre os quais não foram encontradas nenhuma nota biográfica em jornais que circulavam no período ou em livros de memórias produzidos sobre a história da cidade durante a Primeira República, mas que já possuíam casas de telha e taipa ou ranchos no novo bairro e pretendiam oficializar a terra que já ocupavam. Possivelmente Januario Elias era um desses representantes populares, sem vínculo com o poder local, mas também morador do novo território criado.

Não somente os editais divulgados no periódico oficial são capazes de oferecer indícios que demonstram indivíduos mais humildes aforando terrenos no terceiro bairro da cidade. O próprio texto da Resolução n.92 determinava que alguns terrenos do bairro deveriam ser subdivididos em lotes de sete metros de frente por vinte de fundo e destinados "a habitação das pessoas, cujos recursos, por exíguos, Ihes dificultem ou impossibilitem a acquisição, a título oneroso, de terrenos do patrimônio municipal" (A REPUBLICA, 14 maio-14 jun. 1904). Essa determinação não seria exclusiva para o bairro Cidade Nova, também atingindo os bairros Ribeira e Cidade Alta. Contudo, por essa lei, Cidade Nova teria que destinar nove quarteirões para as concessões gratuitas, enquanto Cidade Alta e Ribeira destinavam apenas um.

Esse grande número de quarteirões de Cidade Nova destinados à população menos abastada da cidade parece, à primeira vista, contrariar as diversas matérias publicadas no $A$ Republica exaltando a criação do novo bairro, que deveria representar tudo, menos a pobreza da cidade. O terceiro bairro da cidade era apresentado pelo jornal oficial do Partido Republicano Federal do Rio Grande do Norte e pelas próprias resoluções municipais como promissor, local aprazível e salubre, que deveria abrigar os membros mais abastados de Natal.

Entretanto, vale salientar que Ribeira e Cidade Alta já eram, quando essa lei foi promulgada, bairros muito ocupados, que dividiam a função de moradia com vários comércios e outros tipos de atividades. Já Cidade Nova era, em 1904, aproximadamente dois anos após a sua oficialização, um bairro praticamente despovoado, talvez por isso a resolução determinou para esse bairro um maior número de quarteirões destinado aos menos abastados. Nesse período foi também elaborado um projeto de expansão do novo território, ampliando ainda mais a área urbana da capital:

URBANA, V.6, no 9, ago-dez, 2014 - Dossiê: Dimensões Simbólicas das Intervenções Urbanas CIEC/UNICAMP 


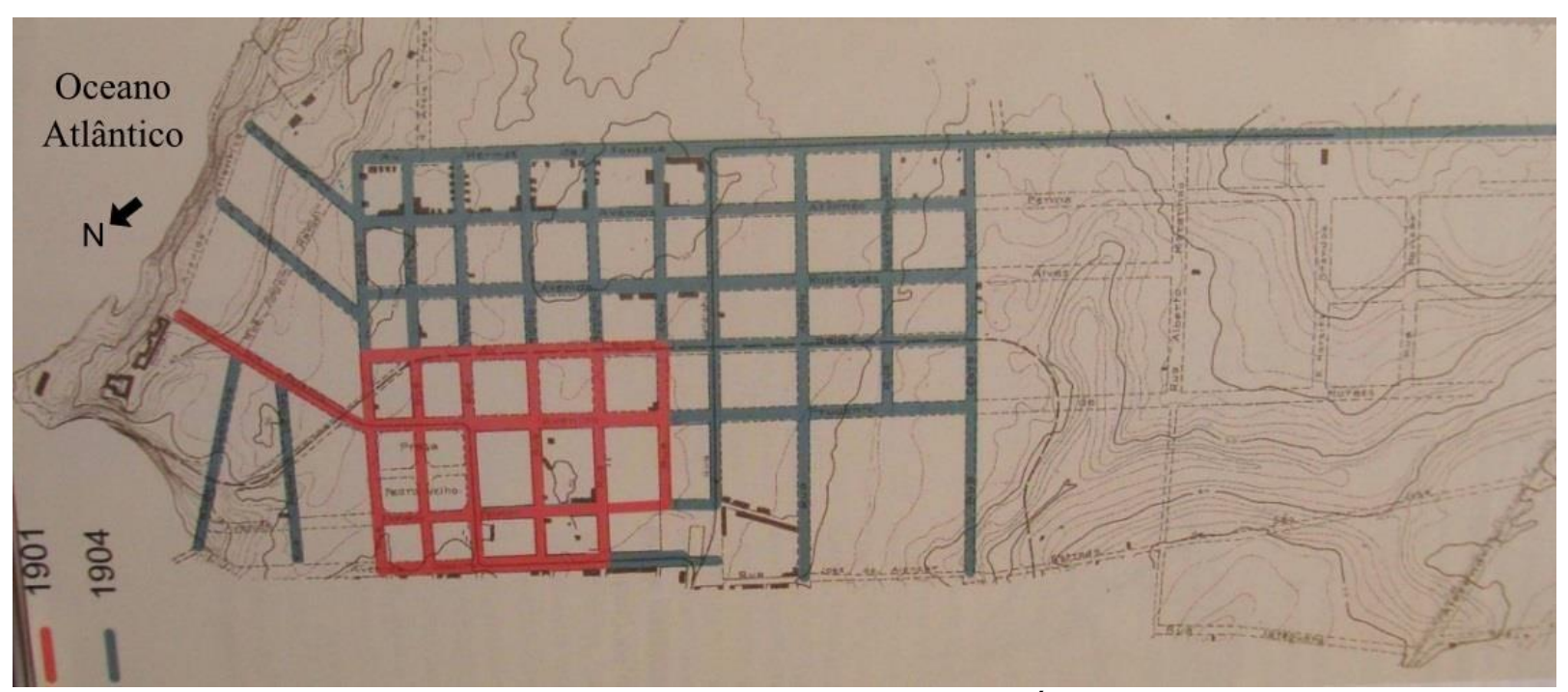

Figura 3 - Representação ressaltando a ampliação da área de Cidade Nova.

Fonte: Adaptação do mapa contido em: (FERREIRA et al, 2008).

Possivelmente, a iniciativa de destinar áreas dos bairros de Natal para aforamentos gratuitos concedidos a populares é mais um exemplo de como novas ideias eram incorporadas nas leis municipais, refletindo os ideais republicanos. A democracia era entendida pelos republicanos como a extinção da sociedade de privilégio, o regime da igualdade (MELLO, 2007, p.141). Com essa determinação sobre os aforamentos gratuitos, a administração municipal demonstrava estar preocupada, pelo menos no texto da lei, em garantir a cidadania, o direito à propriedade aos menos abastados, conforme determinava o $72^{\circ}$ artigo da Constituição de $1891^{22}$.

A população que seria beneficiada com os aforamentos gratuitos não manteria suas moradias fora dos padrões, tendo que respeitar as regras impostas pelo poder municipal. O fiscal do bairro procederia à entrega dos lotes e providenciaria para que "na colocação das casinhas seja rigorosamente observado o alinhamento"(A REPUBLICA, 14 maio-14 jun. 1904). Analisando a situação por esse viés, esse benefício não parece de todo contraditório.Poderia ser encarado como um caminho que o poder municipal encontrou para solucionar o problema da existência de choupanas e casas em péssimas condições, além de vincular o governo a uma ação democrática, preocupada em garantir boas condições de moradias aos menos

\footnotetext{
22 BRASIL. Constituição da República dos Estados Unidos do Brasil, 24 de fevereiro de 1891. Op. cit. Todavia, segundo Raymundo Faoro, mesmo com a promulgação da Constituição de 1891, continuava sendo operada a mesma prática imperial, "em que as fiç̧ões constitucionais assumem o caráter de um disfarce, para que, à sombra da legitimidade artificialmente montada, se imponham as forças sociais e políticas sem obediências às fórmulas impressas. Era a hipocrisia constitucional". Assim, para Faoro, a garantia de normas democráticas no texto da lei não significava que seriam realmente colocadas em prática. Ver: (FAORO, 1975, P.468).
}

URBANA, V.6, no 9, ago-dez, 2014 - Dossiê: Dimensões Simbólicas das Intervenções Urbanas CIEC/UNICAMP 
abastados.

A concessão gratuita dos lotes seria realizada pelo presidente da Intendência, mediante petição enviada pelo aspirante a foreiro, conforme ocorria no processo comum. Entretanto, nesses casos, o candidato a enfiteuta não pagaria pela expedição das cartas de aforamento, nem por seus selos e outros emolumentos. Finalizado o prazo de dez anos, o foreiro poderia requerer o terreno para aforamento definitivo, devendo pagar, a partir de então, metade do valor do foro que era comumente cobrado pela Intendência ${ }^{23}$.

Além dos editais, que podem fornecer pequenos indícios da presença de populares no bairro, ao longo da pesquisa não foram encontradas matérias que se referissem a essas áreas do bairro Cidade Nova destinadas aos menos abastados. Esse silêncio no jornal situacionista pode indicar que essa parte da Resolução n.92 não foi aplicada, ficando reduzida apenas ao texto da lei. A única nota do $A$ Republica que discorreu sobre a iniciativa de construção de casas populares no terceiro bairro da cidade foi divulgada em outubro de 1913. Essa matéria foi publicada na coluna Varias como sendo uma reclamação dirigida em nome dos moradores de Cidade Nova ao presidente da Intendência. O texto destacou que no terceiro bairro da cidade, na avenida Deodoro, projetava-se construir um grupo de pequenas casinhas de tijolo para alugar a preços baratos, em terrenos que pertenciam ao falecido Raymundo Filgueira ${ }^{24}$. Contudo, parece que os moradores da região não estavam muito satisfeitos com a proposta, conforme destacou uma nota enviada ao jornal situacionista por alguns moradores do bairro:

Tratando-se de uma avenida onde se acham edificadas diversas casas de construção moderna e que no futuro há de, por certo, ser uma das melhores da capital, por ser ponto de transito dos tramways, não é justo que se consinta semelhante inconveniente que poderá trazer serias dificuldades. Appellamos, pois, para o ilustre presidente da Intendencia Municipal, esperando que tome as necessárias providencias, não deixando que na avenida Deodoro se levantem casebres que venham a enfeiaraquelle movimentado trecho da linha electrica que conduz ao aprasivel monte Petropolis (A REPUBLICA, 30 out. 1913).

De fato, a avenida Deodoro era uma das principais artérias do bairro Cidade

\footnotetext{
${ }^{23}$ Vale ressaltar que a Resolução n.92, ao instituir regras para a concessão de aforamentos gratuitos, estava repetindo grande parte do texto da Resolução n.87, de outubro de 1903, que já tinha estabelecido áreas de Cidade Nova, entre as avenidas Sétima e Oitava, para concessão dessas terras aos menos abastados. Contudo, a Resolução n.92 ampliou essa lei, acrescentando outros quarteirões de Cidade Nova e os bairros Cidade Alta e Ribeira nessa política de terras destinadas aos mais humildes.

${ }^{24}$ Raymundo Filgueira foi, durante muitos anos, fiscal da Intendência.

URBANA, V.6, no 9, ago-dez, 2014 - Dossiê: Dimensões Simbólicas das Intervenções Urbanas CIEC/UNICAMP
} 
Nova, conforme alegavam os moradores da região. A nota acima destacada reforçava o discurso de exaltação do terceiro bairro, tão elucidado como moderno, progressista, como aquele que, no futuro, mudaria a imagem da cidade. Nesse território promissor, deveriam ser construídos verdadeiros palácios, construções, como asseverou a notícia, modernas, bem diferentes dos casebres que seriam construídos nos terrenos de Filgueira.

A existência de casas humildes, descritas como casebres, viriam a "enfeiar" aquela avenida, sendo um inconveniente aos moradores da região. Porém, deve-se frisar que essa reclamação foi publicada no jornal da situação, que tentava representar o bairro Cidade Nova como símbolo da modernização, ou seja, das transformações técnicas e sociais implantadas na cidade, como território salubre, higiênico, destinado aos mais abastados. Essa nota publicada em 1913 também não foi assinada, não sendo possível afirmar com segurança se realmente tratava-se de uma reclamação enviada por habitantes da região ou se era uma estratégia do jornal da situação para impedir a construção de moradias destinadas a populares.

Essa nota publicada em 1913 não tinha relação direta com os artigos da Resolução n.92 que destinavam quarteirões do bairro para serem aforados gratuitamente pelos menos abastados. A forma de apropriação descrita na nota da coluna Varias era o aluguel e não o aforamento. Ou seja, esses indivíduos menos abastados pagariam determinada quantia aos herdeiros de Filgueira, que seriam os verdadeiros proprietários das casas alugadas. Apesar de não ter relação direta com a legislação elucidada, essa matéria pode ser analisada como um indício de que os moradores mais abastados de Cidade Nova não aprovavam a construção de casas simples, não simpatizavam com a ideia de dividir aquele território. O novo bairro fora criado para segregar, para separar os mais ricos, capaz de oferecer um ambiente salubre, e, segundo os seus moradores, não poderia ser dividido com a população pobre da cidade, que ainda permanecia com costumes tradicionais, representados na imprensa como provincianos.

Embora a Resolução n.92 tenha determinado áreas destinadas aos populares, o fato de não terem sido encontradas matérias no jornal que representava o poder local e outras fontes que permitissem localizar essa população, pode sugerir que essa parte da resolução não foi colocada em prática, demostrando mais um exemplo das limitações do republicanismo implantado na capital, muitas vezes restrito apenas aos textos das leis.

Como pode ser observado por meio da análise da legislação aqui discutida, URBANA, V.6, no 9, ago-dez, 2014 - Dossiê: Dimensões Simbólicas das Intervenções Urbanas CIEC/UNICAMP 
entre 1903 e 1904 inúmeras resoluções municipais foram publicadas tentando regulamentar a política de aforamento na cidade. Nesse período, ocupava o cargo de presidente da Intendência de Natal Joaquim Manoel Teixeira de Moura. Joaquim Manoel, também conhecido pela alcunha de Quincas Moura, ocupou o cargo de presidência do poder municipal entre 1900 e 1913. Era amigo íntimo de Pedro Velho, maior liderança da família Albuquerque Maranhão, que controlava o poder local nesse período, tendo casado sua filha com o filho desse que foi construído como herói republicano local. Observa-se, pois, como o poder estadual interferia no municipal por meio de relações de parentesco e amizade.

Durante a pesquisa, foi possível observar que ao longo da gestão de Quincas Moura, o poder local deu mais atenção à regularização das formas de apropriação do solo urbano da cidade, não publicando apenas resoluções que determinavam o padrão para calcular os preços dos aforamentos, mas promulgando resoluções extensas, que legislavam sobre vários aspectos desse instituto, como a Resolução n.73 e, sobretudo, o grande compêndio expresso na Resolução n.92.

No livro A Intendência e a cidade, os pesquisadores do grupo Os espaços na modernidade elaboraram um estudo sobre as temáticas das resoluções publicadas entre 1892 e 1919 encontradas nos periódicos da cidade e em livros de leis e decretos. Nesse estudo, os pesquisadores constataram que foi durante a segunda gestão de Joaquim Manoel Teixeira como presidente da Intendência, entre 19021904, que um maior número de resoluções determinando regras para aforamento foram publicadas. Nesse período, foram encontradas nove resoluções discorrendo sobre a enfiteuse, enquanto, nos períodos anteriores e posteriores não foram publicadas mais do que três resoluções sobre esse assunto (ARRAIS; ROCHA; VIANA, 2012, p.374-375).

O periódico $A$ Republica também exaltou a iniciativa do então presidente da Intendência. Em agosto de 1903, em matéria intitulada Melhoramentos na cidade, o jornal ressaltou a ação do chefe do poder municipal, que estava empenhado em regularizar o instituto enfitêutico e, para tanto, "com os ilustres membros do concelho de Intendência, tem promulgado leis garantidoras do bem publico e do interesse particular" (A REPUBLICA, 14 ago. 1903). O próprio Joaquim Teixeira, em seu relatório publicado em 1905 sobre a gestão de 1902 a 1904, ressaltou a preocupação que teve com a regularização dos pagamentos dos foros anuais e de outras fontes de renda do poder público:

[...] Um dos meus maiores empenhos como chefe do executivo municipal, foi URBANA, V.6, no 9, ago-dez, 2014 - Dossiê: Dimensões Simbólicas das Intervenções Urbanas CIEC/UNICAMP 
pôr em ordem a escripturação correspondente a foros e outras fontes de renda provenientes do patrimonio. Os novos aforamentos estão sendo feitos com methodo e garantia reciprocas para a Intendencia e para o foreiro; todas as cartas de data, alem do respectivo talão que fica no archivo, são registradas, por quarteirões e bairros, em livro especial, e para cada uma dellas n'outro livro escrupulosamente escripturado, abre-se uma conta corrente para o pagamento de foros. Já por este novo systema foram expedidas até agora, quer originariamente quer em substituição, 357 cartas de aforamento, na importancia de 2:470.000 annuaes, sendo:

No bairro da Cidade Alta - $169 \quad 1: 005.000$

No bairro da Ribeira - 124

857.000

No bairro da Cidade Nova - $42 \quad 434.000$

$\mathrm{Na}$ area suburbana - $22 \quad 174.000$

A estes devem ser ainda addicionadas, perfasendo o numero total de 388, trinta e um aforamentos a titulo gratuito nos quarteirões destinados á pobresa [...] (A REPUBLICA, 19 jan. 1905).

Nota-se como o texto do relatório de Teixeira demonstrava as modificações na política do aforamento que tinham sido imprimidas pelas resoluções publicadas entre 1903 e 1904. Joaquim Manoel ressaltou que as cartas de aforamento deveriam ser registradas por quarteirões e bairros em livro especial, dando maior garantia tanto para o enfiteuta quanto para a detentora do patrimônio aforado, que era a Intendência.

O trecho do relatório de Joaquim Teixeira também demonstrava como, com a atenção especial dada à regularização desse instituto, o município lucrava, tendo aumentado sua receita em dois contos e quatrocentos e setenta mil réis anuais. Ainda nesse mesmo relatório, é possível constatar que os aforamentos em Cidade Nova representavam a terceira posição em relação à contribuição para a receita do poder municipal. Joaquim Manoel também destacou no relatório a existência de aforamentos gratuitos nos quarteirões destinados à população menos abastada da cidade, conforme estabelecido pela Resolução n.92.

O relatório do presidente da Intendência pode ser considerado mais um indício que demonstra como o aforamento também era de certa forma acessível aos populares. No entanto, o documento não especificou em que bairros esses 31 aforamentos gratuitos foram concedidos, não sendo possível constatar, por esse texto, se o terceiro bairro da cidade atendeu de modo expressivo a essa cláusula da Resolução n.92. Como já destacado, existiam, em Cidade Nova, moradores que não integravam os grupos mais influentes da capital, mas os editais e matérias encontrados não explicitaram a forma de apropriação desses indivíduos, se eles tinham acesso à terra por meio de aluguéis, subenfiteuses, enfiteuses gratuitas, ou URBANA, V.6, no 9, ago-dez, 2014 - Dossiê: Dimensões Simbólicas das Intervenções Urbanas CIEC/UNICAMP 
por outra forma de apropriação.

Ainda no mesmo relatório, Joaquim Manoel enfatizou que, apesar dessa preocupação mais sistemática com a regulamentação das enfiteuses de terras do patrimônio municipal, ainda existia muito trabalho a ser realizado. O presidente da Intendência destacou que os terrenos devidamente regulamentados representavam apenas uma parte mínima, se comparado com a grande quantidade de terrenos irregulares ou abusivamente ocupados que ainda existiam na capital natalense.

Em outro relatório, publicado em 1914 sobre a gestão de 1911 a 1913, Joaquim Manoel continuou destacando seu papel no processo de regularização da política de aforamento urbano. Apesar de o texto fazer referência às ações do poder municipal no início da década de 1910, Quincas Moura comentou a sua realização no início dos anos 1900 no tocante à regulamentação da enfiteuse. O presidente da Intendência ressaltou que somente em 1903, com o aumento da população e progressos da cidade, o poder municipal lançou "as vistas para os terrenos doados ao município por D. João VI" (A REPUBLICA, 04 jun. 1914). Joaquim Manoel fazia referência às antigas terras do rossio, doadas pela Coroa às câmaras municipais ainda no período colonial. Essas terras constituíram o patrimônio do poder municipal desde a colônia e permaneceram, agora pertencendo à Intendência, no período republicano.

O presidente da Intendência ressaltou que, antes dessa intervenção de sua gestão em 1903, eram raros os proprietários que possuíam a documentação regularizada de seus aforamentos e pagavam os foros anuais à Intendência, contribuindo para a receita anual do poder municipal com a quantia de apenas um conto de réis (1:000.000). Diante desse quadro de irregularidades, Joaquim Manoel argumentou que:

Urgia organizar um cadastro e normalizar a situação dos posseiros, assegurando a um tempo uma renda vantajosa e fixa. Várias resoluções foram votadas e muitos sacrifícios custaram esses trabalhos preparatórios devido, em sua maior parte, à solicitude e influencia do preclaro estadista que foi o senador Pedro Velho. [...].

O tempo com sua logica inflexível, saldou todo acervo de censuras e injustiças que nos foram prodigalizadas, como sóe acontecer entre gentes incultas e inconsciente de seus deveres cívicos. Como prova do resultado obtido, tenho a satisfação de acusar um rendimento superior a 10:000.000 annuaes, para 2.700 cartas de aforamento, ou seja o decuplo da receita primitiva no espaço de dez anos [...](A REPUBLICA, 04 jun. 1914).

O trecho do relatório de Joaquim Manoel acima citado, apesar de pequeno, é capaz de exemplificar vários discursos do poder local que eram bastante expressivos URBANA, V.6, no 9, ago-dez, 2014 - Dossiê: Dimensões Simbólicas das Intervenções Urbanas CIEC/UNICAMP 
no início do século XX. Nesse relatório, Quincas Moura mais uma vez ressaltou a importância de sua intervenção na política de aforamento urbano, regularizando uma situação que estava sendo bastante desvantajosa para a receita municipal. O relatório também anunciou que essa política de regularização não foi encarada pacificamente.Sacrifícios foram realizados, contestações existiram, mas esses percalços representavam apenas um despreparo de "gentes incultas e inconscientes de seus deveres cívicos"(A REPUBLICA, 04 jun. 1914). Nesse trecho o presidente da Intendência buscou reafirmar a função pedagógica do poder municipal, de civilizar, de ensinar, de mostrar à população, que iniciava os anos de 1900 incultamente, que a capital norte-rio-grandense tinha outro papel a desempenhar, que não podia mais tratar suas políticas de terra com descaso, reforçando, assim, a importância das reformas implementadas por esse poder local.

Outro aspecto importante do trecho mencionado é o incremento da receita municipal graças à regulamentação da política de aforamento urbano. O presidente da Intendência mais uma vez exaltou o seu governo, destacando que na sua gestão conseguiu aumentar consideravelmente a receita anual do poder municipal que, em 1903 era de apenas um conto de réis e, ao final de sua gestão em 1913, era de dez contos de réis.

Ainda nesse mesmo relatório, o presidente da Intendência destacou que, apesar da regularização e do maior controle em relação ao pagamento dos foros anuais, era necessário ainda uma reforma para assegurar o desenvolvimento da edificação, objetivo principal do aforamento para áreas urbanas. Joaquim Manoel enfatizou que era preciso limitar a área dos terrenos concedidos em aforamento, pois, para o intendente, a concessão de verdadeiros latifúndios, "além de não ser equitativa, concentra as propriedades nas mãos dos mais abastados e reduz o número de edificações, em desaccôrdo com o crescimento da população" (A REPUBLICA, 04 jun. 1914). Afirmação que pode ser interpretada como mais um indício de que os ideais de igualdade, democracia, cidadania, de um governo preocupado com a coisa pública, muitas vezes ficavam restritos apenas aos textos da lei e aos discursos oficiais. $O$ referido presidente da Intendência possuía, por exemplo, um terreno de $58.265 \mathrm{~m}^{2}$ em Cidade Nova (NATAL, Carta de aforamento n.12, 30 jan. 1904), bem representativo de um latifúndio. Fato que demonstra como esses sujeitos que compunham o poder local, e eram bem relacionados com os Albuquerque Maranhão, utilizavam de seus cargos para obterem determinados privilégios, como extensos terrenos que desrespeitavam as resoluções vigentes criadas por esses próprios intendentes.

URBANA, V.6, no 9, ago-dez, 2014 - Dossiê: Dimensões Simbólicas das Intervenções Urbanas CIEC/UNICAMP 
A fala de Joaquim Manoel ainda ressaltou um problema que foi apontado em algumas matérias do jornal A Republica: a questão da falta de edificações. Os habitantes aforavam terrenos, mas não cumpriam a cláusula da edificação, ocasionando um problema considerável, já que o aumento populacional não era acompanhado pelo aumento de moradias.

Ao leitor pode parecer estranho que se tenha analisado ao longo desse texto várias resoluções regulamentando o instituto da enfiteuse na década de 1900 e quase não se mencione resoluções sobre essa temática para a década de 1910. De fato, como destacado, as normas previstas pela Resolução n.92, publicada em 1904, permaneceram vigorando na cidade durante muito tempo, como pode ser observado pela análise do texto das resoluções orçamentárias publicadas após a promulgação dessa resolução. As resoluções orçamentárias, ao fixarem a receita e despesa da Intendência para o ano vindouro, acabavam por mencionar algumas regras que determinavam a cobrança do aforamento, já que os foros e laudêmios compunham a receita do poder municipal. Como também já foi destacado, algumas dessas regras foram alteradas pela Resolução n.194, publicada somente em 1916. Todavia, não se teve acesso a todas as mudanças implementadas por essa resolução, já que a mesma não foi encontrada. Contudo, conseguiu-se mapear algumas mudanças, como em relação ao cálculo do aforamento para áreas urbanas, por meio da Resolução orçamentária n.195, que já foram elucidadas.

O ano de 1916 merece destaque não somente pela mudança nas regras de cálculo de foro determinada pela Resolução n.194. Nesse ano, foi elaborado o primeiro Código civil do país, que entraria em vigor no ano seguinte, em 1917. Como já destacado, até a publicação desse código muitas questões civis referentes às formas de apropriação da terra eram reguladas pelas Ordenações Filipinas, com base nas quais muitas leis estaduais e municipais eram elaboradas. Vale ressaltar que a partir de 1850, com a Lei de Terras e o seu regulamento de 1854, muitas determinações das Ordenações foram mantidas, ampliadas ou modificadas. Todavia, em relação ao aforamento, considera-se que o texto das Ordenações Filipinas é mais abrangente, regulando outros aspectos que ficaram ausentes no texto do regulamento de $1854^{25}$, como em relação aos critérios para distribuição de terras aforadas, alienações e cálculo do foro anual. A partir de 1916, o Brasil passou a ter um código, e esse começou a ser utilizado como base para a elaboração das leis locais.

\footnotetext{
25 O regulamento de 1854 somente comentou sobre o instituto do aforamento nos artigos 770 e 790 , ver: DECRETO número 1.318 de 30 de janeiro de 1854. Op. cit.

URBANA, V.6, no 9, ago-dez, 2014 - Dossiê: Dimensões Simbólicas das Intervenções Urbanas CIEC/UNICAMP
} 
Apesar de o Código de 1916 ter legislado sobre a propriedade plena, aquela em que todos os seus direitos elementares acham-se reunidos no do proprietário, essa legislação também discorreu sobre os direitos reais, estando entre eles a enfiteuse ou aforamento. No artigo $678^{\circ}$, do Título II, capítulo II, o código determinou que: "Dá-se a enfiteuse, aforamento, ou emprazamento, quando por ato entre vivos, ou de última vontade, o proprietário atribui a outrem o domínio útil do imóvel, pagando a pessoa, que o adquire, e assim se constitui enfiteuta, ao senhorio direto uma pensão (...)"(BRASIL, 28 abr. 2013). Dessa maneira, é possível perceber como o Código de 1916 manteve o instituto do aforamento, existente no país desde o período colonial.

O Código de 1916 também destacou, em seu artigo 6790, a diferença entre a enfiteuse e o arrendamento, institutos que, pelas suas aparentes semelhanças, podem ser confundidos pelos pesquisadores que estudam as políticas de apropriação do solo urbano. Segundo esse artigo, a enfiteuse difere-se do arrendamento por ser um contrato perpétuo, enquanto o arrendamento possui contrato limitado. A legislação também determinava que somente poderiam ser objetos de enfiteuses terras não cultivadas ou terrenos que se destinassem à edificação. Observa-se como essa legislação regulamentava práticas que já existiam no país. Em Natal, os terrenos urbanos tinham como requisito para serem concedidos em aforamento a necessidade de edificação, enquanto nas áreas suburbanas tinham que ser cultivados.

É possível observar ainda como esse Código ratificava normas para a política de aforamento que foram estabelecidas desde as Ordenações Filipinas, mantendo, por exemplo, as regras para a transação do domínio útil das terras concedidas em enfiteuse. Nessas transações, o foreiro deveria avisar ao senhorio direto sua intenção, e, caso o senhorio liberasse a transação, o enfiteuta deveria pagar o laudêmio, cobrado na razão de $2,5 \%$ sobre o preço da alienação ${ }^{26}$.

Apesar de ratificar várias determinações das Ordenações no tocante à política de aforamento, o Código de 1916 também apresentou algumas inovações, como a estabelecida pelo artigo 6930. Segundo esse artigo, todos os aforamentos, até aqueles constituídos antes da promulgação do código, salvo acordo entre as partes, poderiam ser resgatáveis após $30 \operatorname{anos}^{27}$ de suas constituições. Ou seja, o foreiro

\footnotetext{
${ }^{26}$ Conforme estabelecido no artigo $686^{\circ}$ desse código, ver: BRASIL, Código Civil de 1916. Op. cit.

27 A redação original do Código de 1916 estipula o prazo de 30 anos para a execução do direto de resgate. Contudo, a redação do Código dada pela Lei n.2.437, promulgada em 1955, reduz esse prazo para vinte anos. Finalmente, a redação dada pela Lei n.5.872, de 1972, reduz ainda mais o prazo, que passa a ser de 10 anos. Ver: BRASIL, Código Civil de 1916. Disponível em: URBANA, V.6, no 9, ago-dez, 2014 - Dossiê: Dimensões Simbólicas das Intervenções Urbanas CIEC/UNICAMP
} 
poderia adquirir de fato o terreno aforado, não tendo mais, entre outras obrigações, que pagar o foro ao senhorio, que deixaria de existir. Para ter direito ao resgate, o foreiro deveria pagar ao senhorio o laudêmio sobre o valor atual da propriedade e o valor correspondente a dez pensões anuais. É interessante perceber como esse artigo modificava consideravelmente o instituto da enfiteuse, que era baseado na divisão dos domínios. A possibilidade de o foreiro adquirir plenamente a propriedade pode ser considerada como mais um prenúncio de mudança nessa mentalidade proprietária ${ }^{28}$. Com esse artigo do Código, o aforamento, herança da mentalidade proprietária do medievo, poderia ser transformado em propriedade plena, individual e abstrata.

Em relação ao instituto do aforamento aplicado em Natal, ao longo da pesquisa não foi encontrada nenhuma legislação local que indicasse a incorporação das normas estabelecidas pelo artigo $693^{\circ}$ do Código Civil de 1916. As cartas de aforamento e matérias publicadas no jornal $A$ Republica também não apresentaram exemplos de enfiteuses que foram resgatadas pelos foreiros e tornaram-se propriedades plenas. Provavelmente, essa ausência de fontes pode indicar que essa cláusula presente na legislação federal não foi incorporada pela Intendência de Natal.

\section{Considerações finais:}

Ao longo do artigo, com base na análise das resoluções locais que regulamentaram o instituto da enfiteuse, foi possível constatar como essa política de apropriação do solo urbano fazia parte da mentalidade proprietária da capital norterio-grandense e foi utilizada para ocupar o terceiro bairro da cidade. Essa análise também permitiu observar determinadas mudanças ocasionadas com a construção do governo republicano e várias permanências.

Como visto, o aforamento já era um instituto utilizado pelo poder local para distribuir terras em troca de foro desde o período colonial. Com o governo republicano, as regulamentações desse instituto foram mais bem definidas, com a promulgação de diversas leis minuciosas, que não apenas instituíam o valor do foro a ser cobrado, mas estabeleciam desde regras para expedição de carta, até regras

<http://www.planalto.gov.br/ccivil_03/leis/l3071.htm>. Acesso em: 28 de abr. 2013; BRASIL. Lei n. 2.437, de 07 de março de 1955. Disponível em: <http://www.planalto.gov.br/ccivil_03/leis/19501969/L2437.htm\#art1>. Acesso em: 28 nov. 2013; BRASIL. Lei n. 5.827, de 23 de novembro de 1972. Disponível em: <http://www.planalto.gov.br/ccivil_03/leis/1970-1979/L5827.htm\#art1>. Acesso em: 28 nov. 2013.

${ }^{28}$ Como destacado, a historiadora do direito Laura Beck Varela considera, além do Código Civil de 1916, a Lei de Terras de 1850 e a Lei Hipotecária de 1864 como marcos no processo de passagem da propriedade dividida ou condicionada para a forma jurídica absoluta e individual.

URBANA, V.6, no 9, ago-dez, 2014 - Dossiê: Dimensões Simbólicas das Intervenções Urbanas CIEC/UNICAMP 
voltadas para o processo de alienação das terras aforadas.

De fato, este artigo não analisou de forma minuciosa todas as leis publicadas na colônia e no império referentes às formas de apropriação das terras públicas de Natal por meio do aforamento. Contudo, a análise das resoluções do período republicano permitiu observar mudanças significativas. Como exemplo tem-se a Resolução n.92, que instituiu o cargo de auxiliar técnico da Intendência, funcionário encarregado de verificar os limites dos terrenos dos indivíduos que solicitassem terras em aforamento, bem como reduziu de três para um ano o prazo para o foreiro edificar nos terrenos urbanos aforados. O estudo das resoluções municipais mostram inovações que certamente não existiam no período imperial, em que o privilégio e as relações pessoais eram predominantes no tocante ao tratamento dado à coisa pública.

Já com a construção do regime republicano, ideias de democracia, igualdade, cidadania, separação entre patrimônio público e privado, deveriam perpassar a administração local, e, em Natal, esses ideais estiveram presentes em algumas resoluções municipais, definindo, até mesmo, áreas em que os aforamentos seriam gratuitamente concedidos aos menos abastados, mesmo que essas ideias muitas vezes tenham ficado restritas apenas aos textos das leis.

Outra mudança que o governo republicano imprimiu nessa forma de apropriação de terras estudada foi a possibilidade instituída pelo Código de 1916 do foreiro tornar-se, por meio do direito do resgate, proprietário pleno, no sentido moderno, da terra aforada. Com o pagamento de determinada quantia estipulada pela legislação, o foreiro perderia sua condição, se livraria das obrigações com o antigo senhorio, demonstrando como a mentalidade proprietária moderna tentava impor-se com mais vigor e eliminar resquícios da mentalidade dos domínios divididos.

Apesar dessas modificações citadas ao longo do texto, várias continuidades também foram constatadas pelo estudo dessas leis referentes ao aforamento urbano. A primeira permanência foi o fato do próprio instituto do aforamento ter vigorado em pleno século $X X$, em uma cidade que passava por remodelações urbanas, sociais, que se pretendia modernizada. Todavia, como destacou Grossi, a propriedade é mentalidade, e não se pode considerar como única aquela que é apenas a concepção proprietária dominante em determinado período. Como visto, em Natal, a mentalidade proprietária moderna conviveu com a mentalidade proprietária dos domínios divididos. Apesar das especificidades das diversas resoluções promulgadas durante o recorte estudado, observou-se que o cerne dessa política de distribuição do solo urbano permaneceu. Regras estabelecidas pelas Ordenações Filipinas, como necessidade de URBANA, V.6, no 9, ago-dez, 2014 - Dossiê: Dimensões Simbólicas das Intervenções Urbanas CIEC/UNICAMP 
divulgação em editais, regras para transferência de terras aforadas, cálculo para cobrança de laudêmio, entre várias outras, permaneceram de forma quase idêntica nas resoluções publicadas no período republicano pela Intendência de Natal.

Assim, este artigo demonstrou como o governo republicano instalado no Rio Grande do Norte e, especificamente em sua capital, foi envolto por continuidades não apenas nas práticas de políticos, nas formas de relacionar o público e o privado, nos termos das resoluções, muitas vezes denominadas de posturas, entre outras práticas, mas também esteve presente na mentalidade proprietária. Formas de apropriação do solo urbano tradicional conviveram com formas consideradas modernas.

Observou-se, ainda, várias resoluções discorrendo sobre uma mesma temática ligada ao aforamento, constituindo, com isso, irresoluções que foram incorporadas e bem utilizadas pelos foreiros de Cidade Nova. Como ressaltou o jornal oposicionista Diário do Natal, em 1907, "isso de lei immutavel é um obstáculo aos interesses privados dos imperantes republicanos" (DIARIO DO NATAL, 17 mar. 1907).

\section{Referências}

ALVEAL, Carmen Margarida Oliveira; DANTAS, Aledson Manoel Silva (2013). Foro da discórdia: mudanças jurídicas no status da propriedade sesmarial nas Capitanias do Norte. (texto digitalizado).

ARRAIS, Raimundo; ROCHA, Raimundo Nonato Araújo; VIANA, Hélder do Nascimento (orgs) (2012). A Intendência e a cidade: fontes para o estudo da gestão da cidade do Natal (1892-1919). Natal: Editora da UFRN.

AMORIM, Edgar Carlos de (1986). Teoria e prática da enfiteuse. Rio de Janeiro: Editora Forense.

BRITO, Anderson Dantas da Silva (2012). Em nome(s) dos interesses: imaginários toponímicos do Rio Grande do Norte na Primeira República. Dissertação (Mestrado em História). Universidade Federal do Rio Grande o Norte. Natal.

BUENO, Almir de Carvalho (2002). Visões de República: ideias e práticas políticas no Rio Grande do Norte (1880-1895). Natal: Editora da UFRN.

(1999). Visões de República: ideias e práticas políticas no Rio Grande do Norte (1880-1895). Tese (Doutorado em História). Programa de PósGraduação em História, Universidade Federal de Pernambuco (UFPE), Recife.

CóDIGo Filipino ou Ordenações e Leis do Reino de Portugal: recompiladas por mandado d'el-Rei Dom Felipe I. Ed. Fac. - similar da $14^{\circ}$ ed. de 1821. In: ALMEIDA, Candido Meneses de (org.) (2004). Brasília: Edições do Senado Federal, Conselho URBANA, V.6, no 9, ago-dez, 2014 - Dossiê: Dimensões Simbólicas das Intervenções Urbanas CIEC/UNICAMP 
Editorial.

CONGOST, Rosa (abr. 2000). Sagrada propriedade imperfecta. Otravisión de larevolución liberal española. História Agrária, n.20, p.61-93.

FAORO, Raymundo (1975). Os donos do poder: formação do patronato político brasileiro. v. 2. São Paulo: Editora da Universidade de São Paulo.

FONSECA, Cláudia Damasceno (2011). Arraiais e vilas d'el rei: espaço e poder nas Minas setecentistas. Belo Horizonte: Editora da UFMG.

FERREIRA, Angela Lúcia (1996). De la producción Del espacio urbano a la creación de territórios em la ciudad: um estudio sobre la constitución de lo urbano en Natal, Brasil. Tese (Doutorado em Geografia Humana). Universidade de Barcelona, Barcelona.

FERREIRA, Angela Lúcia et al (2008). Uma cidade sã e bela: a trajetória do saneamento de Natal - 1850-1969. Natal: IAB/RN; CREA/RN.

GLEZER, Raquel (2007). Chão de terra e outros ensaios sobre São Paulo. São Paulo: Alameda.

GROSSI. Paolo (2006). A propriedade e as propriedades na oficina do historiador. In: . Historia da propriedade e outros ensaios. Rio de Janeiro: Renovar. . (2007). Mitologias jurídicas da modernidade. Florianópolis: Fundação Boiteux.

HOLSTON, James (fev. 1993). Legalizando o ilegal: propriedade e usurpação no Brasil. Revista Brasileira de Ciências Sociais, ano 08, n.21.

JÚNIOR STAUT, Sérgio Said (2009). A posse no direito brasileiro da segunda metade do século XIX ao Código Civil de 1916.Tese (Doutorado em Direito). Programa de Pós-Graduação em Direito, Universidade Federal do Paraná (UFPR), Curitiba.

MELLO, Maria Tereza Chaves de (2007). A república consentida: cultura democrática e científica no final do Império. Rio de Janeiro: Editora da Universidade Federal Rural do Rio de Janeiro.

MIRANDA, João Mauricio Fernandes de (1981). 380 anos de história foto-gráfica da cidade de Natal 1599-1979. Natal: Editora da UFRN.

MONTEIRO, Denise Mattos (2007). Terra e trabalho em perspectiva histórica: um exemplo do sertão nordestino (Portalegre: Rio Grande do Norte). In: Terra e trabalho na história: estudos sobre o Rio Grande do Norte. Natal: Editora da UFRN. 
MOTTA,Márcia Maria Menendes (2008). A lei de terras e seus significados. In: Nas fronteiras do poder: conflito e direito a terra no Brasil do século XIX. Niterói: Editora da UFF.

PEIXOTO, Renato Amado (2012). Espacialidades e estratégias de produção identitária no Rio Grande do Norte no início do século XX. In: PEIXTO, Renato Amado (org.). Nas trilhas da representação: trabalhos sobre a relação entre história, poder e espaços. Natal: Editora da UFRN.

SANTOS, Renato Marinho Brandão (2012). Natal, outra cidade!: o papel da Intendência municipal no desenvolvimento de uma nova ordem urbana (1904-1929). Dissertação (Mestrado em História). Programa de Pós-Graduação em História, Universidade Federal do Rio Grande do Norte (UFRN), Natal.

SILVA, Marcio Antônio Both da (2011). Entre a lei e a sua aplicabilidade: a gestão das "terras devolutas" na região de matas do Rio Grande do Sul durante a Primeira República (1889-1925). In: MOTTA, Márcia; SECRETO, Maria Verônica (Orgs.). $O$ Direito às avessas: por uma história social da propriedade. Guarapuava: Unicentro. SIQUEIRA, Gabriela Fernandes de (2014). Por uma "Cidade Nova": apropriação e uso do solo urbano no terceiro bairro de Natal (1901-1929). Dissertação (Mestrado em História). Programa de Pós-Graduação em História, Universidade Federal do Rio Grande do Norte (UFRN), Natal.

SOUZA, Carlos André Feliz (2012). Terrenos de marinha e terras devolutas no Rio Grande do Norte (1831-1889). Trabalho de Conclusão de curso (Graduação em História). Curso de História, Universidade Federal do Rio Grande do Norte (UFRN), Natal.

TEIXEIRA, Rubenilson Brazão (2009). Da cidade de Deus à cidade dos homens: a secularização do uso, da forma e da função urbana. Natal: Editora da UFRN.

VARELA, Laura Beck (2005). Das sesmarias à propriedade moderna: um estudo de história do direito brasileiro. Rio de Janeiro: Renovar.

URBANA, V.6, no 9, ago-dez, 2014 - Dossiê: Dimensões Simbólicas das Intervenções Urbanas CIEC/UNICAMP 